\title{
Pore-water pressure development in a frozen saline clay under isotropic loading and undrained shearing
}

\author{
Chuangxin Lyu ${ }^{1}$ (1) -Satoshi Nishimura ${ }^{2} \cdot$ Seyed Ali Ghoreishian Amiri ${ }^{1} \cdot$ Feng Zhu $^{3} \cdot$ Gudmund Reidar Eiksund $^{1}$. \\ Gustav Grimstad ${ }^{1}$
}

Received: 7 October 2020 / Accepted: 16 August 2021 / Published online: 7 October 2021

(C) The Author(s) 2021

\begin{abstract}
A systematical testing program on frozen Onsøy clay under isotropic loading and undrained shearing at different temperatures $\left(-3 \sim-10{ }^{\circ} \mathrm{C}\right)$, strain rates $(0.2 \sim 5 \% / \mathrm{h})$ and initial Terzaghi effective stress $(20 \sim 400 \mathrm{kPa})$ was conducted with the focus on pore pressure development. It is meant to increase the understanding and facilitate the development of an 'effective stress'-based model for multi-physical analysis for frozen soils. This study adopted the pore pressure measurement method suggested by Arenson and Springman (Can Geotech J 42 (2):412-430, 2005. https://doi.org/10.1139/t04111 ) and developed a new testing procedure for frozen soils, including a 'slow' freezing method for sample preparation and post-freezing consolidation for securing hydraulic pressure equilibrium. The B-value of frozen soils is less than 1 and significantly dependent on temperature and loading history. The dilative tendency or pore pressure development in an undrained shearing condition is found to be dependent on both unfrozen water content and mean stress, which is consistent with unfrozen soils. Besides, the experimental results reported in the literature regarding uniaxial tests show that the shear strength does not share the same temperature- and salinity-dependency for different frozen soil types. The rate dependency of frozen soils is characterized between rate dependency of pure ice and that of the unfrozen soil and is therefore highly determined by the content of ice and the viscous behavior of ice (through temperature dependency). This paper also explains the pore pressure response in freezing and thawing is dependent on volumetric evolution of soil skeleton.
\end{abstract}

Keywords B-value $\cdot$ Frozen soil $\cdot$ Pore pressure $\cdot$ Shear strength $\cdot$ Soil skeleton

\section{Introduction}

Frozen saline soil has aroused great attention and concern to both geotechnical and permafrost engineering regarding permafrost degradation, landslides, ground freezing and infrastructure stability [4, 22, 41, 44]. Mechanical behavior of frozen saline soils can be distinctive from well-studied frozen non-saline sand not only because of lower strength

Chuangxin Lyu

chuangxin.lyu@ntnu.no

1 Department of Civil and Environmental Engineering, Norwegian University of Science and Technology (NTNU), 7491 Trondheim, Norway

2 Division of Field Engineering for the Environment, Faculty of Engineering, Hokkaido University, Hokkaido, Japan

3 Department of Architectural Engineering, Shandong Business Institute, Shandong, China but also due to significant unfrozen water content (UWC) above the eutectic temperature $[5,8,9,16,34]$.

Some efforts have been made on understanding uniaxial strength of frozen saline soils, which is a function of soil types, salinity, strain rate and temperature [16, 32, 33, 37], while triaxial test with focus on mechanical behavior under confinement condition has received less attention and has not formed a standard experimental framework, compared with unfrozen soils $[21,51,52]$. On the one hand, the boundary condition in most of triaxial tests for frozen soil remains unclear. For example, Arenson and Springman [3], Lai et al. [21] and $\mathrm{Xu}$ et al. [52] measured quite high volumetric strain up to $2-3 \%$ in undrained condition, during triaxial shearing when the applied stress was far below the melting pressure. These results indicate either quite high air content in the frozen samples or shear-induced cracks during the tests, and the application of these 
results to the development of constitutive models requires caution.

On the other hand, the mean and deviatoric stress-induced pore pressure development at high UWC condition can play important roles in mechanical and hydrological analyses of frozen saline soil $[13,31]$, and an effective stress model with the consideration of pore pressure can be a better option for thermo-hydro-mechanical modeling than a total stress model. However, the study of load-induced pore pressure development for frozen soil is quite scarce, although pore-water pressure in frozen soil has been measured for other kinds of investigation, such as freezing and thawing tests $[15,18,54]$, cryogenic suction at the water-ice interface $[19,30]$, and water redistribution in one dimensional freezing process $[40,56,57]$.

Arenson and Springman [3] measured pore pressure development in triaxial loading of ice-rich frozen soils in undrained condition, while zero volumetric deformation was not secured because of high air-content in the samples. The results validate the method in which anti-freezing liquid is applied to keep the connectivity between pore pressure sensors and unfrozen water phase based on the measurement consistency between the pore pressure development and volumetric change. Zhang et al. [53] adopted miniature pore pressure transducers to measure water pressure at the bottom of the testing samples while water can flow through porous stone at the top. The boundary condition of testing was similar to 1D oedometer test with top end drainage. It is problematic for both Arenson and Springman [3] and Zhang et al. [53] results to be considered as the response of representative elementary samples. Kia [18] measured the pore-water pressure response under isotropic undrained loading for frozen saline sand and studied the effect of pre-consolidation pressure and temperature on the pore-water pressure coefficient (B-value). However, the study did not cover the excess water pressure induced by deviatoric stress.

In this work, we followed the experimental method suggested by Arenson and Springman [3] to investigate pore pressure development in undrained isotropic loading and deviatoric shearing for a natural saturated marine clay, Onsøy clay, with $50 \%$ clay fraction and $20-30 \mathrm{~g} / \mathrm{L}$ salt content. Besides, this study proposes a 'slow' freezing technique to prepare the artificially frozen samples to minimize the temperature gradient and then consolidate them to secure the pore pressure equilibrium inside the frozen sample before loading. A series of B-value tests was conducted ahead of the undrained shear tests with excess pore pressure measurement. We present the effect of mean stress, unfrozen water saturation $S_{w}$ (defined as the ratio of volumetric unfrozen water content to the porosity $n$ ), temperature, salinity and strain rate effect on mechanical behaviors of frozen Onsøy clay, especially highlighting the pore pressure response. In the end, the paper discusses two aspects: (1) Pore pressure response in undrained shear test with varying temperature; (2) Pore pressure response and the deformation patterns with varying strain rate.

\section{Material and methods}

\subsection{Onsøy clay}

The Onsøy soft clay site, established in the late 1960s, is located in the southeast of Norway [26]. The site has been well characterized by the Norwegian GeoTest Sites Project at two locations, South Central (SC) with typical salinity $30 \mathrm{~g} / \mathrm{L}$ and water content $70 \%$ and South East Corner (SEC) with $20 \mathrm{~g} / \mathrm{L}$ salinity and $45 \%$ water content [14]. The clay consists of glacial rock flour, clay minerals (mainly chlorite and illite), quartz and feldspars with typically $50 \%$ clay and $50 \%$ silt content. The typical plasticity limit and liquid limit are $20 \%$ and $60 \%$, respectively. The soil is expected to be normally consolidated, but the apparent pre-consolidation can be observed due to aging/ creep. The cooling curve method was used to measure freezing point around $-1.6 \sim-2.2{ }^{\circ} \mathrm{C}$ for the tested material [17, 58].

Natural and remolded Onsøy clay samples were used in this study. The thin walled tube to core natural samples was driven by $\phi 72 \mathrm{~mm}$ Geonor piston. Both sampling dimensions and coring techniques have been proven to provide 'very good to excellent' sample quality since volumetric strain of these samples when they are consolidated back to in situ stresses is less than 0.04 [27]. The remolded Onsøy clay was also prepared firstly by adding predetermined amount of saline water to the sample to increase the water content slightly above the liquid limit. The brine salinity should be same as the salt content of pore fluid in the sample, and sea salt was used for brine preparation because it is closer to the concentration of composites in the pore fluid of Onsøy clay. The mixture slurry was filled into an odometer mold with $\phi 70 \mathrm{~mm}$ inner diameter and then vibrated by hand-hold vibrator for further elimination of gas bubble inside the slurry. The $65 \mathrm{kPa}$ vertical stress was applied with two-end drainage, and the consolidation process normally took 3 days until the water flow was sufficiently slow. This study followed the standard ASTM D2216 to determine the water content, and ASTM D4542 and D1125 to extract pore water and determine salt content in the pore fluid. Both results were consistent with Gundersen et al. [14]. 


\subsection{Triaxial apparatus}

The B-tests and undrained shear tests were conducted in a temperature-controlled triaxial compression apparatus as shown in Fig. 1a. To eliminate the disturbance of frozen soil when it was installed into the triaxial cell and provide a better temperature control, the whole apparatus was placed in a temperature-controlled cold room with $\pm 2{ }^{\circ} \mathrm{C}$ fluctuation. Thermal $\mathrm{H} 5$, an anti-freeze refrigerant with $-50 \sim+105{ }^{\circ} \mathrm{C}$ working temperature, was used for confining and temperature-controlled fluid inside the triaxial cell. The feedback control of cell temperature was achieved by adopting a refrigerated circulator to circulate Thermal H5 through a spiral copper coil inside the cell. The temperature of circulating fluid was adjusted continuously based on the difference between target temperature and measurement of a thermocouple $30 \mathrm{~mm}$ away from the sample. The combination of the temperature feedback control and a double insulation layer can achieve \pm $0.02{ }^{\circ} \mathrm{C}$ accuracy.

The high-resolution loading frame adopted in the setup is capable of constant strain rate or constant-stress loading test. An LVDT with $50 \mathrm{~mm}$ measuring range and \pm 0.01 $\mathrm{mm}$ accuracy was mounted with loading rod to measure the axial displacement. The curved surface of top cap was designed to obtain a point-plane contact for a perfect coupling between top cap and loading rod. Two piston pumps were used to control the cell and back pressure. The cell pressure pump was also filled with the same Thermal $\mathrm{H} 5$ as the triaxial apparatus and the refrigerated circulator. The mixture of water and ethylene glycol as a chemically inactive anti-freezing refrigerant was adopted for saturation of the filter paper, porous stone, back pressure pump and drainage pipeline to maintain the pore pressure transmission at cold temperature. The concentration of ethylene glycol in the mixture should be carefully adjusted to achieve the freezing temperature slightly below testing temperature, relatively low concentration can minimize the thawing effect on frozen soils. A back pressure $\mathrm{p}_{\mathrm{b}}$ was applied in some tests to further saturate the system during the consolidation. A pore pressure transducer with $2 \mathrm{MPa}$ measurement range and $2 \mathrm{kPa}$ accuracy was connected with the frozen samples through a short drainage pipeline to measure the pore pressure variation in the different loading tests.

\subsection{Testing procedures}

The whole workflow was composed of five stages for both natural and remolded samples: sample freezing, consolidation, pre-shearing B-test (isotropic loading), undrained shearing and post-shearing B-test. The preparation of artificially frozen soil, as a key step, remains controversial and still lacks a well-recognized method. According to the freezing direction, it can be categorized as the multiaxial freezing [24, 47] or uniaxial freezing [3, 34]. The latter method is more frequently adopted to model massive soilice structure, a layered structure of ground freezing projects, and frost heave, instead of providing an elementary sample with smaller-scale features [2]. However, water redistribution and local ice crystallization can still be expected even in the multiaxial freezing method because of the evitable thermal gradient between inner and outer parts of samples during the preparation.

In order to overcome or minimize this, 'fast' freezing is often applied by using much lower temperature such as $-30{ }^{\circ} \mathrm{C}$ [38] and liquid nitrogen lower to $-196{ }^{\circ} \mathrm{C}$ [45] to freeze samples and then warming them back to the testing temperature. This method can cause two concerns. The application of $-20 \sim-30^{\circ} \mathrm{C}$ freezing temperature might not be low enough to reach 'fast' freezing for larger samples. For instance, in food industry, fast freezing of blueberries using liquid nitrogen keeps the original microstructure of the product, but static freezing at $-18{ }^{\circ} \mathrm{C}$ results in significant damage [36]. Given the considerably greater sample size of soil than blueberry, it requires even lower temperature at the boundary and hence faster freezing, if the microfabric is to be kept intact. Even if this was possible, such an intact microfabric would not be representative of in situ fabric. The other concern is the dependency of UWC in frozen samples on freezingthawing process. Bittelli et al. [7] and Tian et al. [43] found that UWC at a given temperature is higher in the cooling process. As a result, the frozen soil prepared by this 'fast' freezing method could be stronger because fast freezing involved the process of warming back to a target temperature.

Wang et al. [47] suggested the application of confinement stress during the freezing to realize the field freezing conditions closely and eliminate unnatural radial cracking in high-plasticity clay, which was obviously caused by cylindrical sample geometry. However, Dai et al. [10] found the dependency of the hydrate growth mode on the balance between the local effective stress and the capillary pressure developed by hydrate-water interface, and much higher confining stress is needed when the soil grain size becomes smaller. For instance, the order of $100 \mathrm{kPa}$ effective stress might be enough for sand and silt to develop a pore-filling growth mode or hydrate invasion, while the prevention of crystal replacement in clay may need more than $100 \mathrm{MPa}$ grain contact stress. For lowplasticity Onsøy clay, confinement was not applied during freezing because it will not prevent meso-structure development due to ice crystallization, and no obvious non- 


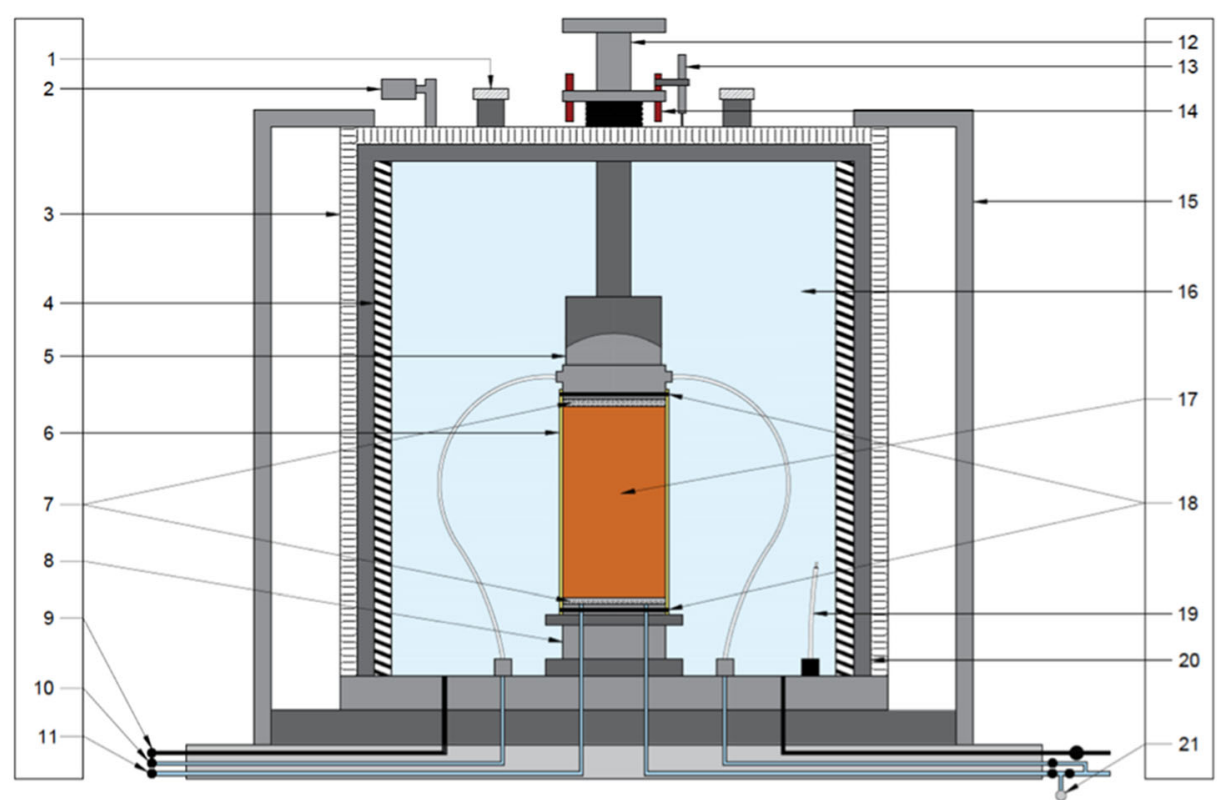

1 Fluid Circulation Valve

2 Air Valve

3 Cell Wall Insulation

4 Coil

5 Top Cap

6 Rubber Membrane

7 Porous Stone

8 Bottom Pedestal
9 Cell Valve
10 Bottom Cap Valve
11 Top Cap Valve
12 Loading Rod
13 Local LVDT
14 Plastic Cylinder

(a)
15 Metal Insulation Panel

16 Cell Fluid

17 Test Sample

18 O-ring

19 Thermometer

20 Cell wall

21 Pore Pressure Sensor

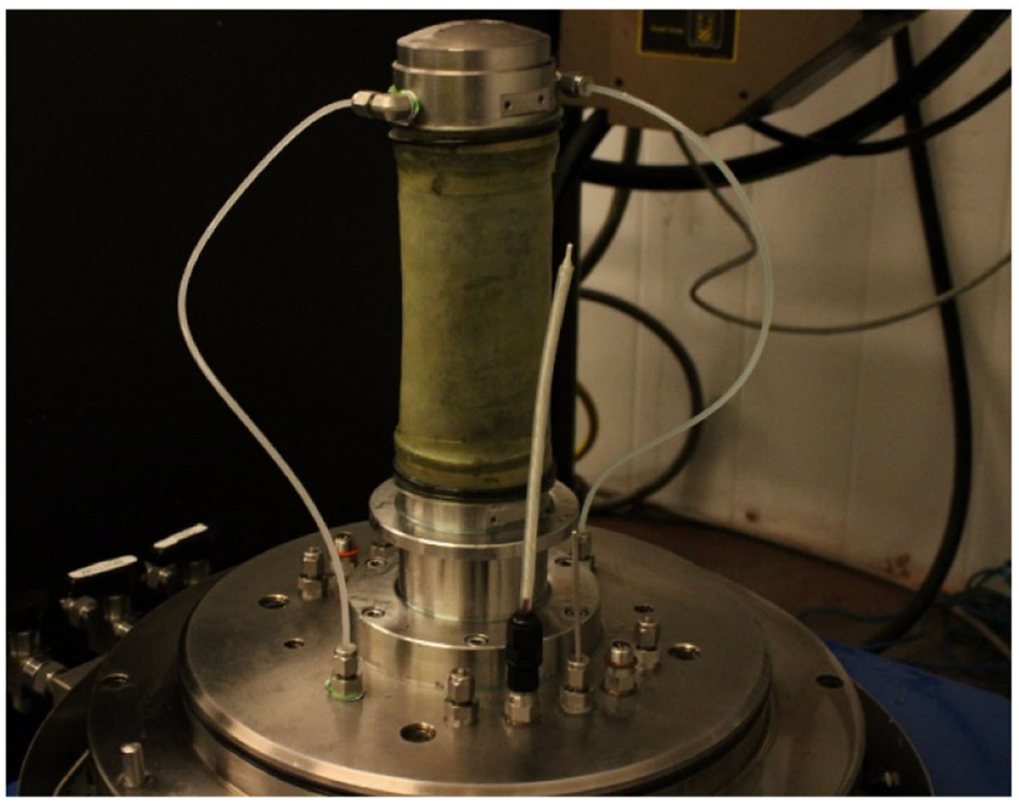

(b)

Fig. 1 a Schematic diagram of the triaxial apparatus; b Setup specimen. (Note: the actual scale is not followed in (a). The cell volume is around $50 \mathrm{~L}$, and the thermocouple is $3 \mathrm{~mm}$ away from sample.) 
uniformity was detected under freezing regime described below.

Instead of 'fast' freezing method, we propose a novel 'slow' freezing technique with the purpose of preparing a representative frozen soil sample. This method allows the growth of local ice crystals with much smaller dimension than the sample and relatively homogeneous distribution. It is also more representative of the natural freezing process in cold regions. It should be also noted that a universal preparation method of artificial frozen samples is difficult to be reached due to various freezing conditions of natural soils. Figure 2 suggests the procedure of 'slow' freezing as following. The cylindrical soil sample was placed inside the membrane, and two edges are sealed by two metal end caps through the O-rings to maintain it waterproof during the freezing. The sealed sample $(\approx 0.6 \mathrm{~L})$ was immersed into a $12 \mathrm{~L}$ volume container filled with anti-freezing liquid, and the whole setup (including the sample and freezing liquid) was put inside a low freezing rate freezer. The temperature is lowered down to $1{ }^{\circ} \mathrm{C}$ and kept for $12 \mathrm{~h}$ to ensure the thermal equilibrium of the sample before the target freezing temperature is set. The whole freezing process takes at least $48 \mathrm{~h}$ because of the large thermal capacity and low freezing rate of the system. The goal of the 'slow' freezing is to significantly lower the thermal gradient between the boundary and the inside of the sample compared with air freezing method, and this method can significantly minimize water redistribution and cryogenic suction. Figure 3 shows the X-ray tomography of frozen samples prepared by air and liquid freezing at the temperature of $-5{ }^{\circ} \mathrm{C}$, which was conducted in the University of Grenoble. The preliminary results indicate that the 'slow' freezing can achieve more uniform ice distribution with much smaller characteristic dimension of ice crystals

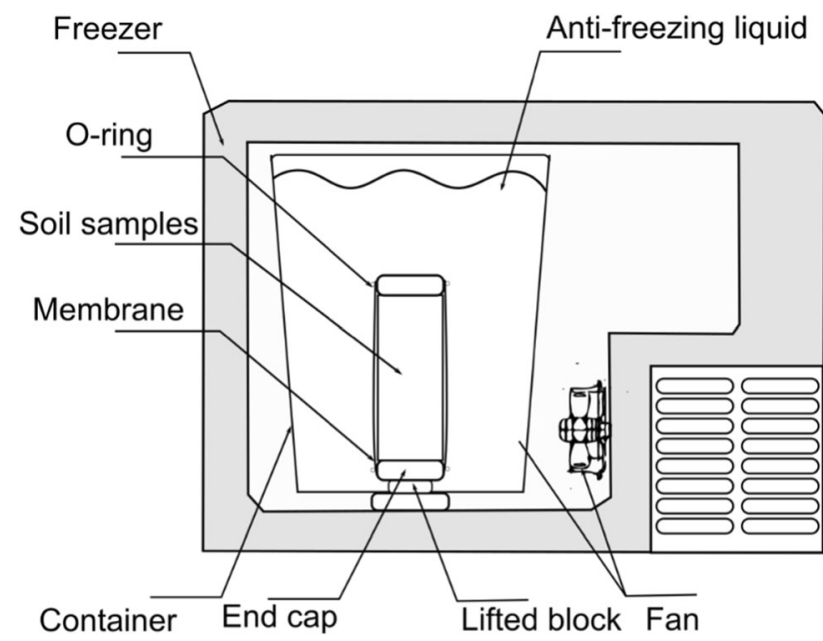

Fig. 2 Setup for slow freezing of soil specimen (Note: the actual scale is not followed. The freezer volume is around $20 \mathrm{~L}$, and container volume is $12 \mathrm{~L}$.) compared with air freezing, and less variation of their scale along the radius. However, more effort is needed to investigate the effect of freezing methods on the physical properties (e.g., the mechanical behavior) of artificial frozen soil to determine the proper standard freezing method.

After the frozen soil was prepared and built into the triaxial cell, cell pressure $\sigma_{3}$ was applied to run the consolidation process, while observing the expelled fluid out of the frozen sample. However, the expelled volume was limited within the volume resolution of back pressure pump and impossible to be accurately determined. Besides we used the back pressure $\mathrm{p}_{\mathrm{b}}$ to facilitate the saturation of system and increase the measurable tension range of fluid during loading. The $\mathrm{p}_{\mathrm{b}}$ was set significantly lower than the cell pressure, so that the water flow is always from the specimen. The consolidation was complete until the expelled volume became stable.

In the following step, pore pressure coefficient (B-value) for frozen soils at the tested temperature $(-3,-5$ and $-10^{\circ} \mathrm{C}$ ) was measured. Cell pressure $\sigma_{3}$ was increased by $\Delta \sigma_{3}=20 \mathrm{kPa}$ in each step, until achieving total $100 \mathrm{kPa}$ increase from the consolidation stress, under undrained boundary condition. The pressure was then decreased back to the start point following the same path. The measured $\mathrm{B}$-value was calculated as the ratio $\Delta u / \Delta p$ after pore pressure was stabilized in each step. The modern highpressure stainless steel tubing and rigid pore pressure sensor design result in quite low system compressibility $[6,28,29]$. The unfrozen water volume in the frozen sample at the coldest testing temperature (around $100 \mathrm{~mL}$ at $-10{ }^{\circ} \mathrm{C}$; calculated based on the UWS measurement results) is also much larger than the extra fluid volume (around $3 \mathrm{~mL}$ ) of the pore pressure line in the setup. With consideration of all efforts, this paper recognizes the measured B-value approximated as the actual B-value.

The undrained shear test was conducted at the same temperature starting with $1 \% / \mathrm{h}$ strain rate. In order to test the strain rate effect on the mechanical strength and pore pressure response, we conducted a multi-stage tests with varying strain rate in some tests listed in Table 1. Wang et al. [47] observed that the strain rate effect on the deviatoric strength seen in the multi-stage test was consistent with results based on the constant strain rate testing. Besides, this study also tested the reproducibility of experimental results by comparing the deviatoric stress and pore pressure response during shearing for two similar remolded frozen soils under same experimental condition. One undrained shear test with varying temperature was also conducted to highlight pore pressure response with freezing and thawing. Samples after shearing typically showed a quite homogenized cylindrical deformation as expected for REV testing. Eventually, post-shearing 


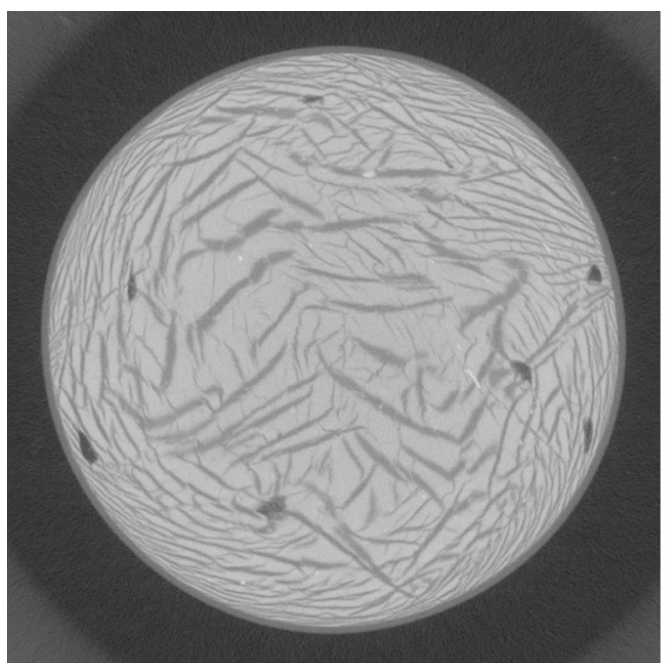

(a) Air freezing: horizontal section

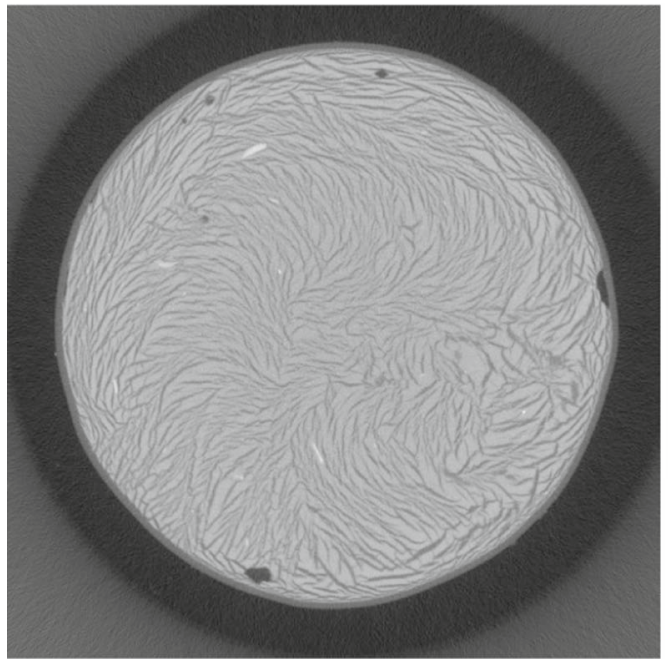

(c) 'Slow' freezing: horizontal section

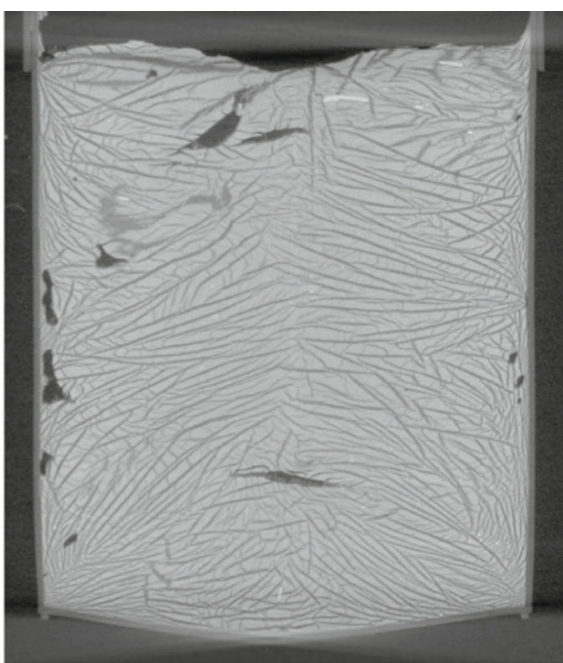

(b) Air freezing: vertical section

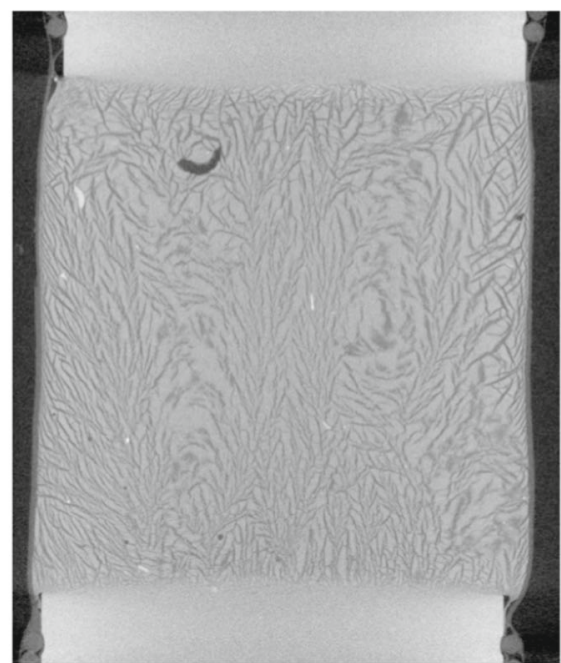

(d) 'Slow' freezing: vertical section

Fig. 3 X-ray scanning of frozen samples prepared by air and liquid freezing (diameter: $70 \mathrm{~mm}$ )

measurement of B-value was conducted again after the deviatoric stress was relaxed back to zero.

\section{Testing results}

\subsection{Pore pressure coefficient}

The measured pore pressure coefficient can be used to distinguish the mean stress-induced and shear-stress-induced excess pore pressure during shearing. This study observed the increase in B-value from 0.32 to 0.76 before and after shearing for $\mathrm{S}=30 \mathrm{~g} / \mathrm{L}$ samples at $-5^{\circ} \mathrm{C}, 0.44$ to $0.85,0.25$ to 0.65 and 0.15 to 0.55 for $\mathrm{S}=20 \mathrm{~g} / \mathrm{L}$ samples at $-3{ }^{\circ} \mathrm{C},-5{ }^{\circ} \mathrm{C}$ and $-10^{\circ} \mathrm{C}$, respectively.
This study observed the decrease in B-value for lower temperature, and the significant increase in B-value after shearing. More detailed discussion of B-value for frozen soils will be discussed in future publication.

\subsection{Strength and excessive pore pressure in undrained shearing}

Following the test procedure described in Sect. 2.3, we firstly conducted undrained shear tests of two frozen remolded soils (ii-1 and ii-2) with similar water content and salinity to check the reproducibility of experimental results. The deviatoric stress $\left(q=\sigma_{1}-\sigma_{3}\right)$ and excess pore pressure $(\Delta u)$ results for both samples at the range of $0-10 \%$ axial strain $\left(\varepsilon_{\mathrm{a}}\right)$ are presented in Fig. 4. It proves 
Table 1 Frozen soil tests

\begin{tabular}{|c|c|c|c|c|c|c|c|}
\hline Test no. & Type & Depth \& site & $T\left({ }^{\circ} \mathrm{C}\right)$ & $S(g / L)$ & $\mathrm{wc}(\%)$ & $p^{\prime}=\sigma_{3}-\mathrm{p}_{\mathrm{b}}(\mathrm{kPa})$ & Axial strain rate $(\% / \mathrm{h})$ \\
\hline $\mathrm{i}-1$ & Natural & $\begin{array}{l}6.6-8 \mathrm{~m} \\
(\mathrm{SEC})\end{array}$ & -5 & 30 & 68 & 100 & 1 \\
\hline $\mathrm{i}-2$ & Natural & $\begin{array}{l}6.6-8 \mathrm{~m} \\
(\mathrm{SEC})\end{array}$ & -5 & 30 & 71 & 200 & $1 / 10$ \\
\hline$i-3$ & Natural & $\begin{array}{l}6.6-8 \mathrm{~m} \\
(\mathrm{SEC})\end{array}$ & -5 & 30 & 68 & 400 & 1 \\
\hline $\mathrm{i}-4$ & Natural & $\begin{array}{l}10-11 \mathrm{~m} \\
(\mathrm{SC})\end{array}$ & -3 & 20 & 52 & 20 & $1 / 0.2 / 5$ \\
\hline$i-5$ & Natural & $\begin{array}{l}10-11 \mathrm{~m} \\
(\mathrm{SC})\end{array}$ & -3 & 20 & 48 & 100 & $1 / 0.2 / 5$ \\
\hline$i-6$ & Natural & $\begin{array}{l}10-11 \mathrm{~m} \\
(\mathrm{SC})\end{array}$ & -3 & 20 & 48 & 200 & $1 / 5$ \\
\hline $\mathrm{i}-7$ & Natural & $\begin{array}{l}10-11 \mathrm{~m} \\
(\mathrm{SC})\end{array}$ & -3 & 20 & 52 & 400 & 1 \\
\hline i-8 & Natural & $\begin{array}{l}10-11 \mathrm{~m} \\
(\mathrm{SC})\end{array}$ & -5 & 20 & 48 & 100 & $1 / 0.2 / 5$ \\
\hline i-9 & Natural & $\begin{array}{l}11-12 \mathrm{~m} \\
(\mathrm{SC})\end{array}$ & -5 & 20 & 44 & 200 & $1 / 0.2 / 5$ \\
\hline $\mathrm{i}-10$ & Natural & $\begin{array}{l}11-12 \mathrm{~m} \\
(\mathrm{SC})\end{array}$ & -5 & 20 & 37 & 400 & 1 \\
\hline i-11 & Natural & $\begin{array}{l}10-11 \mathrm{~m} \\
(\mathrm{SC})\end{array}$ & -10 & 20 & 52 & 100 & $1 / 0.2 / 5$ \\
\hline i-12 & Natural & $\begin{array}{l}11-12 \mathrm{~m} \\
(\mathrm{SC})\end{array}$ & -10 & 20 & 49 & 200 & $1 / 0.2 / 5$ \\
\hline i-13 & Natural & $\begin{array}{l}11-12 \mathrm{~m} \\
(\mathrm{SC})\end{array}$ & -10 & 20 & 38 & 400 & $1 / 0.2 / 5$ \\
\hline ii-1 & Remolded & $\mathrm{i}-1 \& \mathrm{i}-2$ & -5 & 30 & 47 & 200 & $1 / 0.2 / 5$ \\
\hline ii -2 & Remolded & $i-1 \& i-2$ & -5 & 30 & 50 & 200 & 1 \\
\hline iii-1 & Natural & $\begin{array}{l}10-11 \mathrm{~m} \\
(\mathrm{SC})\end{array}$ & $-4 \sim-5$ & 20 & 50 & 100 & 1 \\
\hline
\end{tabular}

Note: T (temperature, ${ }^{\circ} \mathrm{C}$ ); $\mathrm{S}$ (salinity, g/L); wc (gravimetric water content); $\mathrm{p}^{\prime}$ (Terzaghi mean effective stress, $\left.\mathrm{kPa}\right) ; \sigma_{3}(\mathrm{cell} \mathrm{pressure}, \mathrm{kPa}) ; \mathrm{p}_{\mathrm{b}}$ (back pressure, $\mathrm{kPa}$ )

that the experimental result in the undrained shear test of frozen soils is reproducible, although the dual yield point was observed for the sample ii-1 and not for ii-2.

This paper adopted Terzaghi mean effective stress p' as the subtraction between total mean stress $\mathrm{p}$ and pore pressure u presented in Eq. (1) for further analysis:

$p^{\prime}=p-u=\frac{\left(\sigma_{1}^{\prime}+2 \sigma_{3}^{\prime}\right)}{3}$

where $\sigma_{1}{ }^{\prime}=\sigma_{1}-u$ and $\sigma_{3}{ }^{\prime}=\sigma_{3}-u$ are the effective axial and confining stresses, respectively. This way can highlight the maximum contribution of pore pressure to effective stress. Figure 5, 6, 7 and 8 present the $\mathrm{q}-\varepsilon_{\mathrm{a}}-\Delta u-\mathrm{p}^{\prime}$ results with the variation of $100 \sim 400 \mathrm{kPa}$ initial mean effective stress under different testing conditions (e.g., temperature and sample properties).
As these figures indicate, all tested samples showed a ductile response and steady plastic deformation with slightly hardening behavior for some of test results regardless of temperature $\left(-3 \sim-10{ }^{\circ} \mathrm{C}\right)$, strain rate $(0.2 \sim 5 \% / \mathrm{h})$ and initial mean effective stress $(100 \sim 400 \mathrm{kPa})$. The samples i-6, i-8 and i-12 also experienced dual yield point, and the lower yield point was observed at the strain range of $1 \sim 2 \%$. The excess pore pressure $\Delta u$ at the lower yield point either slowed down, as in i-6 and i-12, or even temporarily decreased, as in i-8. Wang et al. [47] attributed the phenomenon to the brittle failure of ice bonding. In this paper, the $\Delta u$ measurement suggested a more dilative deformation tendency in the lower yield point due to breaking of ice bonding. The skeleton of frozen soil was rearranged, and $\Delta u$ increased again when the frozen soil passed though the lower yield 


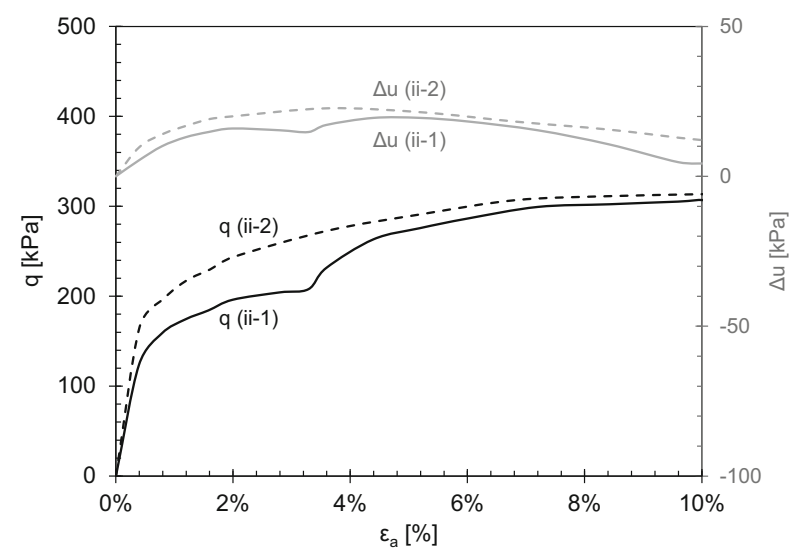

Fig. 4 Duplicate tests for repeatability check: comparison of ii-1 and ii-2 experimental results

point. Besides, the effect of mean stress and unfrozen water content has a significant impact on excess pore pressure. For example, the excess pore pressure of the sample increased with the increase in $p^{\prime}$ when the samples (i-6 and i-7) were compared with the samples (i-4 and i-5). The excess pore pressure is also positively dependent on UWC as $\Delta u$ for the samples (i-4 i-7) tested at $\mathrm{T}=-3{ }^{\circ} \mathrm{C}$ are significantly higher than the samples tested at $\mathrm{T}=-5^{\circ} \mathrm{C}$ (i-8 $\sim \mathrm{i}-10)$ and $-10{ }^{\circ} \mathrm{C}(\mathrm{i}-11 \sim \mathrm{i}-13)$. The strain rate change from $1 \% / \mathrm{h}$ to $5 \sim 10 \% / \mathrm{h}$ for both i-2 and i- 6 tests was conducted after the previous $1 \% / \mathrm{h}$ stage was finished in $12 \mathrm{~h}$, and $\Delta u$ decreased with the relaxation of deviatoric stress q. The rest of multi-stage tests (i-4, i-5, i-8, i-9, i-11, i-12 and i-13) changed the strain rate from the previous stage without relaxation. The more detailed parametric study is discussed in the later analysis. Here, the pore pressure response right after the sudden change in loading rate or at the end of test may not reflect full equilibrium (for example i-9). However, the clear convergence of pore pressure was observed in most of cases. We select the excess pore pressure $\Delta u$ at the $10 \%$ strain (at $1 \% / \mathrm{h}$ strain rate loading) for further data analysis regarding pore pressure development (Fig. 9a).

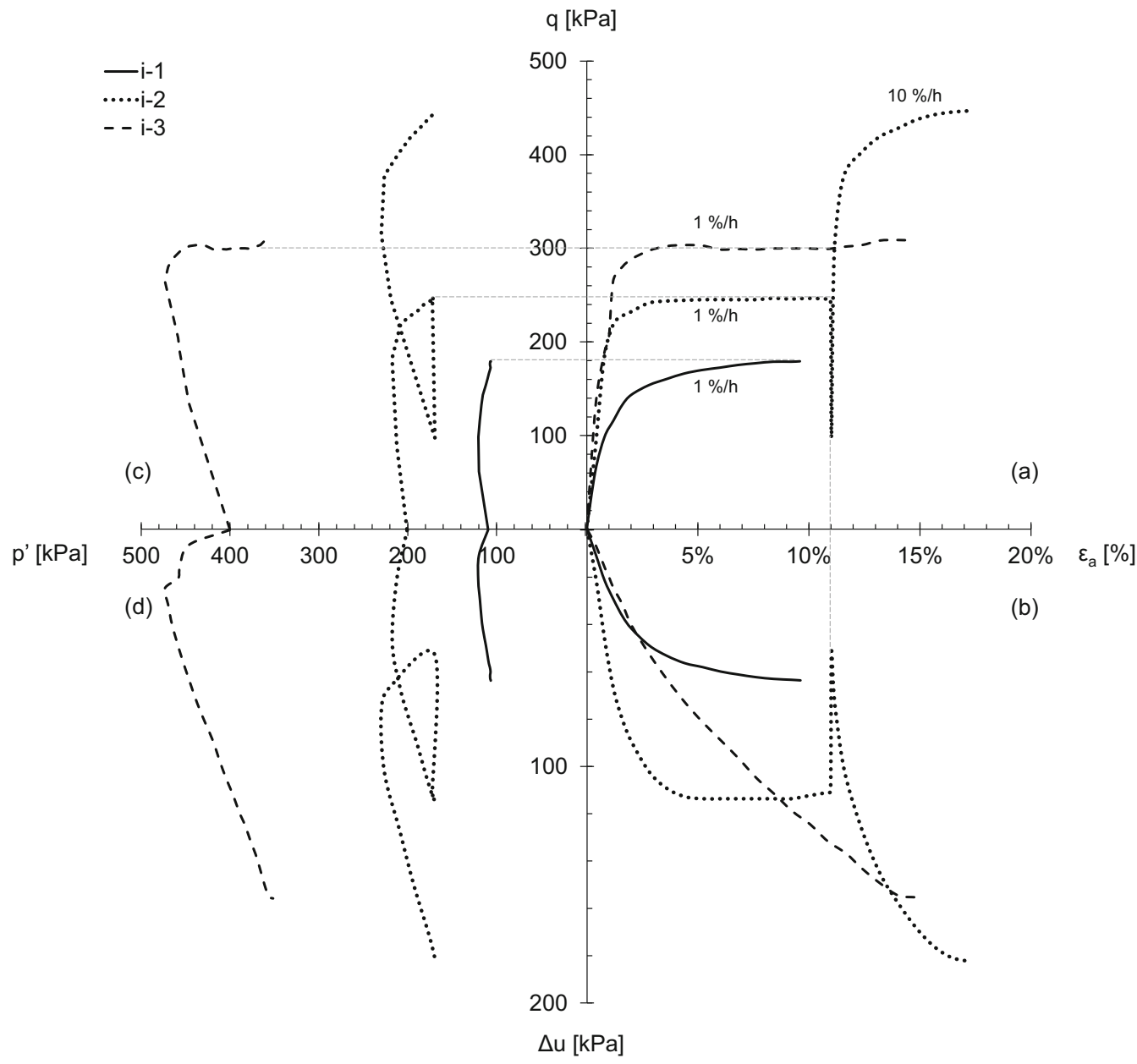

Fig. 5 Undrained shear test results of $\mathrm{i}-1, \mathrm{i}-2$ and $\mathrm{i}-3\left(\mathrm{~S}=30 \mathrm{~g} / \mathrm{L} \& T=-5^{\circ} \mathrm{C}\right)$ : a $q$ vs. $\varepsilon_{\mathrm{a}} ; \mathbf{b} \Delta u$ vs. $\varepsilon_{\mathrm{a}} ; \mathbf{c} q$ vs. $\mathrm{p}^{\prime} ; \mathbf{d} \Delta u$ vs. $\mathrm{p}^{\prime}$. ( $\varepsilon_{\mathrm{a}}:$ axial strain, $q$ : deviatoric stress, $\mathrm{p}^{\prime}$ : Terzaghi mean effective stress, $\Delta u$ : excess pore pressure) 


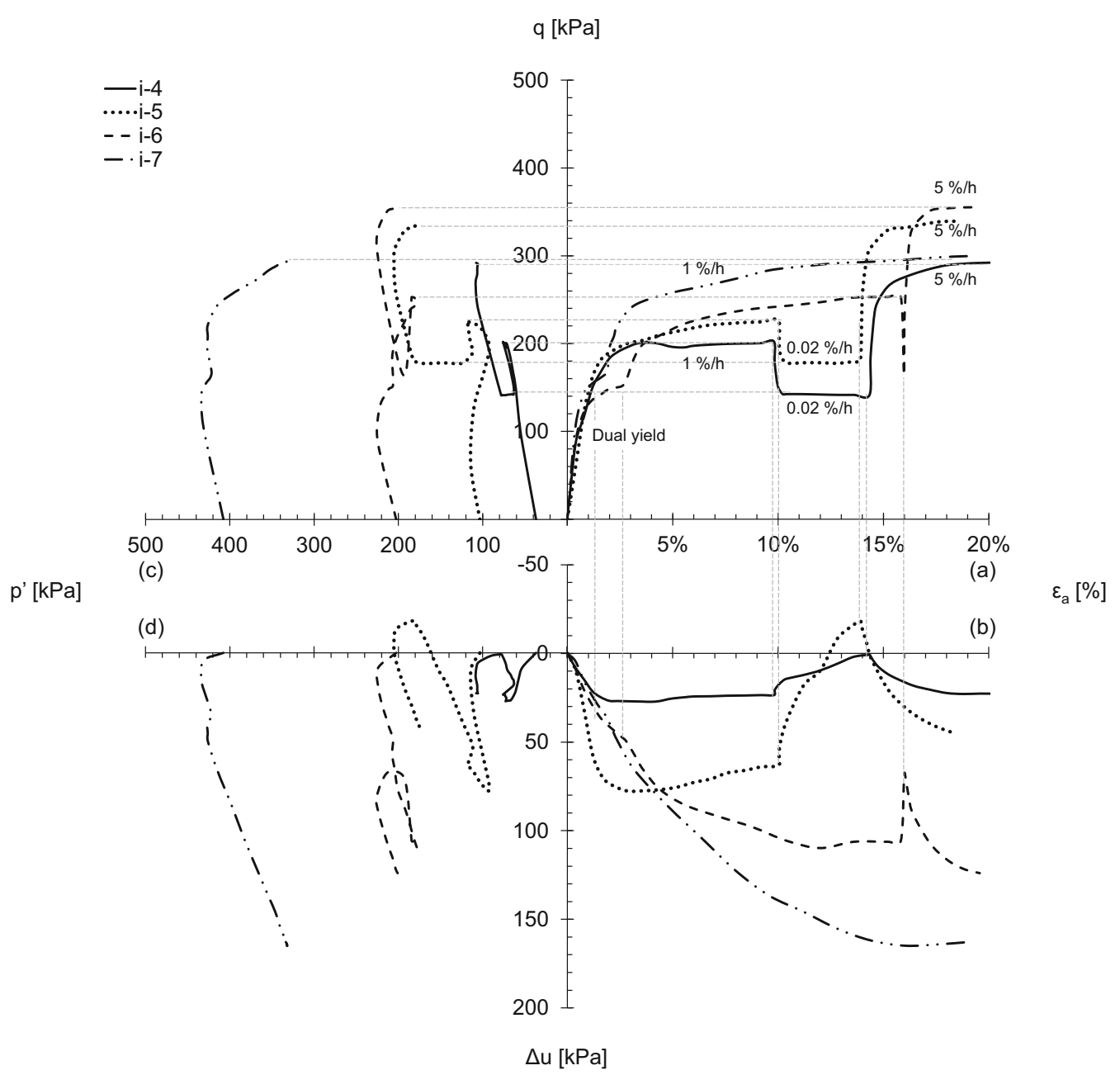

Fig. 6 Undrained shear test results of i-4, i-5, i-6 and i-7: a $q$ vs. $\varepsilon_{\mathrm{a}} ; \mathbf{b} \Delta u$ vs. $\varepsilon_{\mathrm{a}} ; \mathbf{c} q$ vs. $\mathrm{p}^{\prime} ; \mathbf{d} \Delta u$ vs. p'. ( $\varepsilon_{\mathrm{a}}$ : axial strain, $q$ : deviatoric stress, p': Terzaghi mean effective stress, $\Delta u$ : excess pore pressure)

\subsubsection{Effect of mean effective stress and unfrozen water content}

In the classical critical state concept for unfrozen soil, mean effective stress not only contributes to the soil strength but also determines the compression or dilation tendency of soils together with void ratio (loose or dense state) [50]. Similar effects were also observed in our tests on the frozen samples as shown in Fig. 9, which presents the values of $\Delta u$ and $q$ at $1 \% / \mathrm{h}$ strain rate. Variations in both mean stress $\mathrm{p}$ and deviatoric stress $q$ during the shearing contribute to the total $\Delta u$ value, shown as white markers in Fig. 9a. For the determination of the deformation tendency for tested samples, this paper follows the analysis originally proposed by Skempton [42] to calculate the mean stress-induced $\Delta u$ by multiplying $\mathrm{B}$-value to $\Delta p$. The rest $(\Delta u-\mathrm{B} \times \Delta p)$ is the deviatoric stress-induced $\Delta u$, presented as gray marker in Fig. 9a. This method has widely been adopted for the study of rock and cement
$[12,25,29,46]$. The lower and higher B-value measured before and after shearing suggested the upper and lower bound of deviatoric stress-induced $\Delta u$. We observed three key phenomenon: (1) q-induced $\Delta u$ rises with an increase in mean effective stress for i- $1 \sim \mathrm{i}-3, \mathrm{i}-4 \sim \mathrm{i}-7, \mathrm{i}-8 \sim \mathrm{i}-9$ and $\mathrm{i}-11 \sim \mathrm{i}-12$ samples; (2) the excess pore pressure is much higher for frozen soils with higher UWC at warmer temperature (i-4 $\sim$ i-7 vs. i-8 $\sim$ i-10); (3) the total and q-induced $\Delta u$ for i-10 and i-13 (with $400 \mathrm{kPa}$ initial mean effective stress) are slightly lower than both for i-11 and i-12 samples (with $200 \mathrm{kPa}$ initial mean effective stress), respectively. We also found that the void ratio $\mathrm{e} \approx 1$ for i-10 and i-13 samples is lower than $\mathrm{e} \approx 1.2$ and 1.3 for $\mathrm{i}-11$ and i-12 samples before freezing, which indicates that frozen soils with higher void ratio contain higher UWC at a given temperature and results in more compressive (less dilative) deformation tendency.

By applying Terzaghi effective stress, this paper defines $\Delta \mathrm{q} / \Delta p^{\prime}$ ratio, M, as the slope of Critical State Line (CSL) 


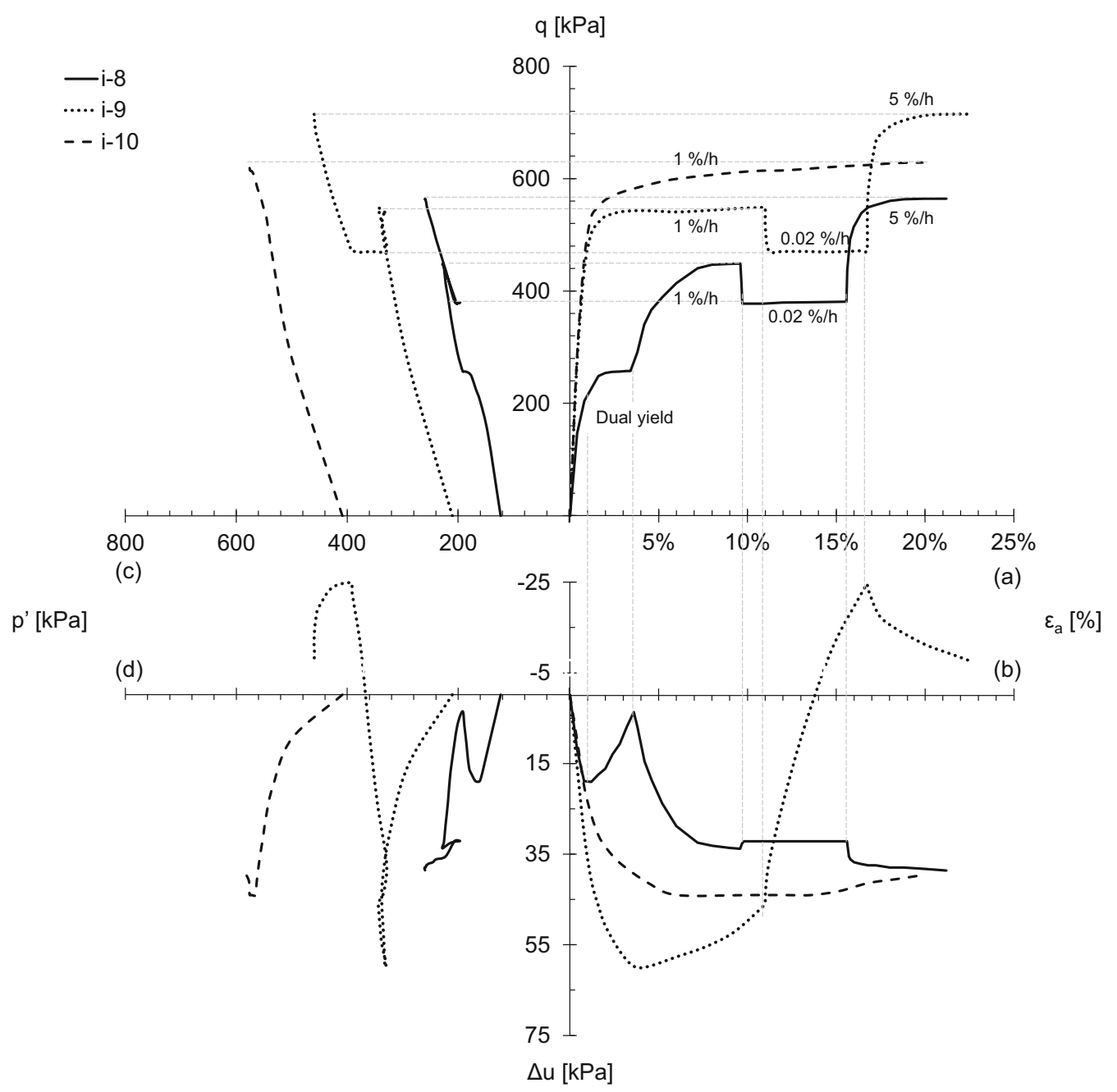

Fig. 7 Undrained shear test results of i-8, i-9 and i-10: a $q$ vs. $\varepsilon_{\mathrm{a}} ; \mathbf{b} \Delta u$ vs. $\varepsilon_{\mathrm{a}} ; \mathbf{c} q$ vs. $\mathrm{p}^{\prime} ; \mathbf{d} \Delta u$ vs. $\mathrm{p}^{\prime}$. ( $\varepsilon_{\mathrm{a}}$ : axial strain, $q$ : deviatoric stress, $\mathrm{p}^{\prime}$ : Terzaghi mean effective stress, $\Delta u$ : excessive pore pressure)

with the nonzero intercept at $\mathrm{p}^{\prime}=0$ because of ice resistance. Another parameter $\mathrm{M}^{*}$ is defined as $\Delta q / \Delta p$ ratio in the total stress analysis. The M-value of frozen Ons $\varnothing y$ clay ranges from $0.3 \sim 0.5$ at relatively higher UWC $(\mathrm{i}-1 \sim \mathrm{i}-$ 10 samples) to 0.8 at the lower UWC (i-11 $\sim 1-13$ ), which is smaller than the reported $\mathrm{M} \approx 1.2$ for unfrozen Onsøy clay [27]. The small M-value explains steady plastic deformation instead of significant softening or hardening behaviors with $\Delta u$ development for frozen Onsøy clay. Andersland, Ladanyi [2] suggested several typical values of friction angle which corresponds to $\mathrm{M}^{*}=0 \sim 0.36$ for frozen clays, $0.57 \sim 0.98$ for frozen silts and $1.16 \sim 1.5$ for frozen sands based on a total stress analysis. Figure $9 \mathrm{~b}$ also shows that an $\mathrm{M}^{*}=0.25$ based on the mean stress $\mathrm{p}$ shifts to $\mathrm{M}=0.4$ when Terzaghi mean effective stress $\mathrm{p}^{\prime}$ is considered. Wang et al. [47] deduced the 'effective' mean stress dependency of Kasaoka Clay and reported increasing $\mathrm{M}$ with decreasing temperature, which is consistent with the experimental results in this paper. The pressure melting effect, which can weaken the frozen soil strength and increase UWC, is out of the scope for this paper since it can become more significant only when the confining pressure $\sigma_{3}$ reaches the order of $\mathrm{MPa}$ or even $10 \mathrm{MPa}$.

\subsubsection{Effect of temperature and salinity on frozen soil strength}

This section discusses the combined effects of temperature $\left(0 \sim-10^{\circ} \mathrm{C}\right)$ and salinity $(0 \sim 30 \mathrm{~g} / \mathrm{L} \mathrm{NaCl})$ on the strength regarding different frozen soil types, since both highly influence the unfrozen water content [16]. Figure 10 presents experimental results of Onsøy clay and some other materials including sands, silts, clays and ice reported in the literature $[16,33,35]$. For clarity, the strength is normalized by $-10{ }^{\circ} \mathrm{C}$ value in Fig. 10a and by the value at the $0 \mathrm{~g} / \mathrm{L}$ salinity in Fig. 10b for a given soil type. The former clearly shows the tendency of increasing strength with decreasing temperature and also highlights two other 


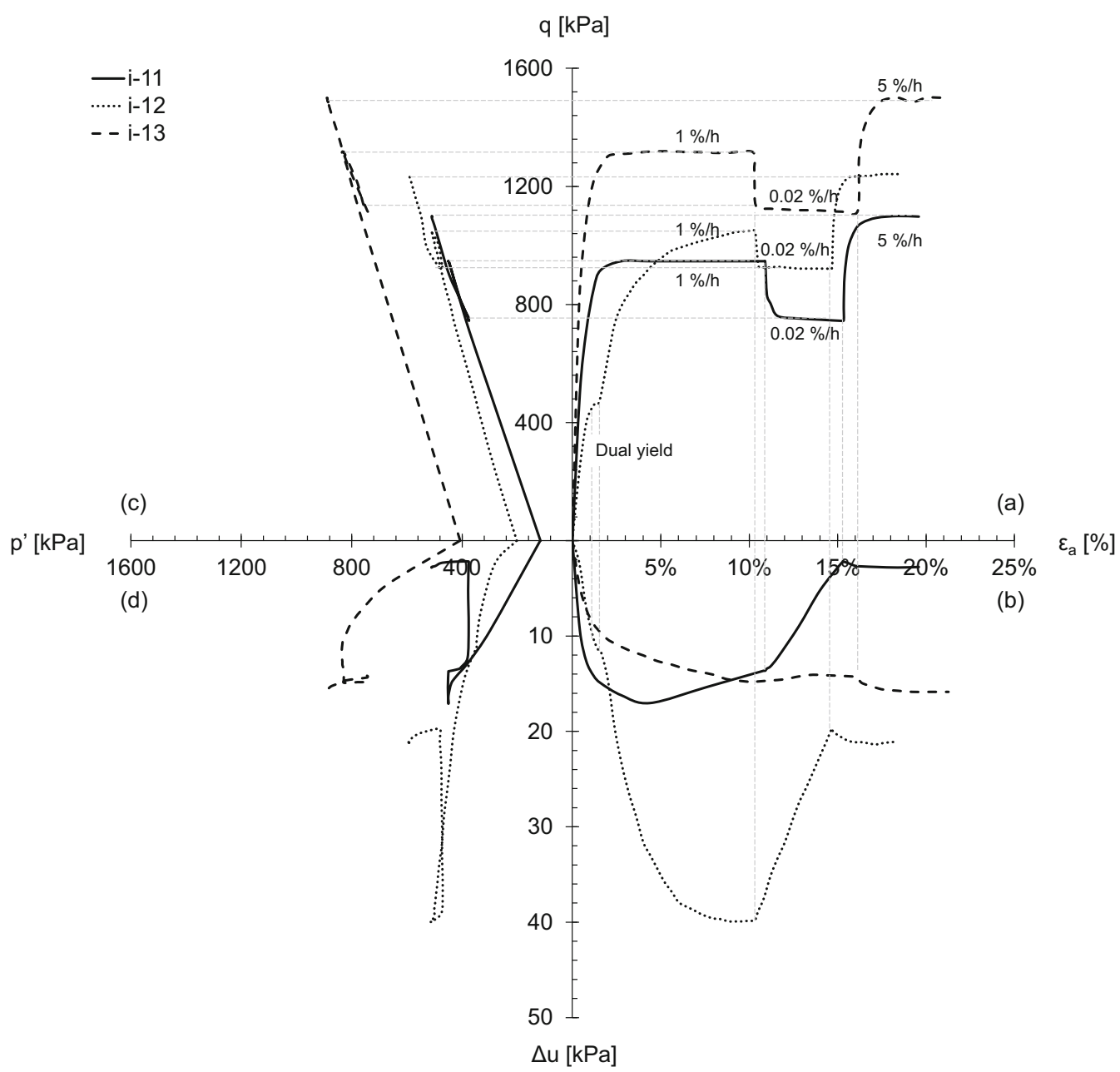

Fig. 8 Undrained shear test results of i-11, i-12 i-13: a $q$ vs. $\varepsilon_{\mathrm{a}}$; b $\Delta u$ vs. $\varepsilon_{\mathrm{a}} ; \mathbf{c} q$ vs. $\mathrm{p}^{\prime}$; d $\Delta u$ vs. p'. ( $\varepsilon_{\mathrm{a}}$ : axial strain, $q$ : deviatoric stress, $\mathrm{p}^{\prime}$ : Terzaghi mean effective stress, $\Delta u$ : excess pore pressure)
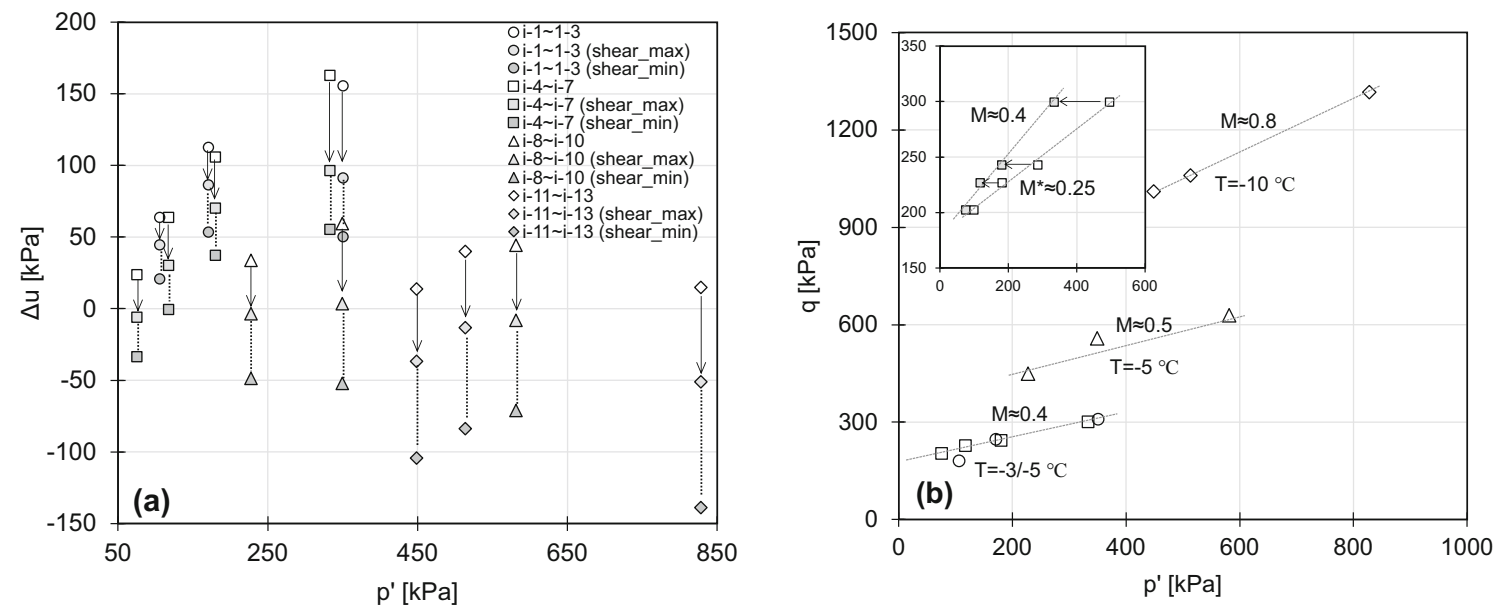

Fig. 9 Observed change of pore pressure $(\Delta u)$ and shear resistance $(q)$ : a $\Delta u$ response; $\mathbf{b} q$ response

observations: (1) the normalized strength of different materials (ice and soils) shares similar variations with temperature to that of ice at the non-saline condition $(0 \mathrm{~g} /$
L) indicated by the line 1. (2) the normalized strength of saline ice and frozen soils as a function of temperature varies with different soil types suggested by the line 2 and 

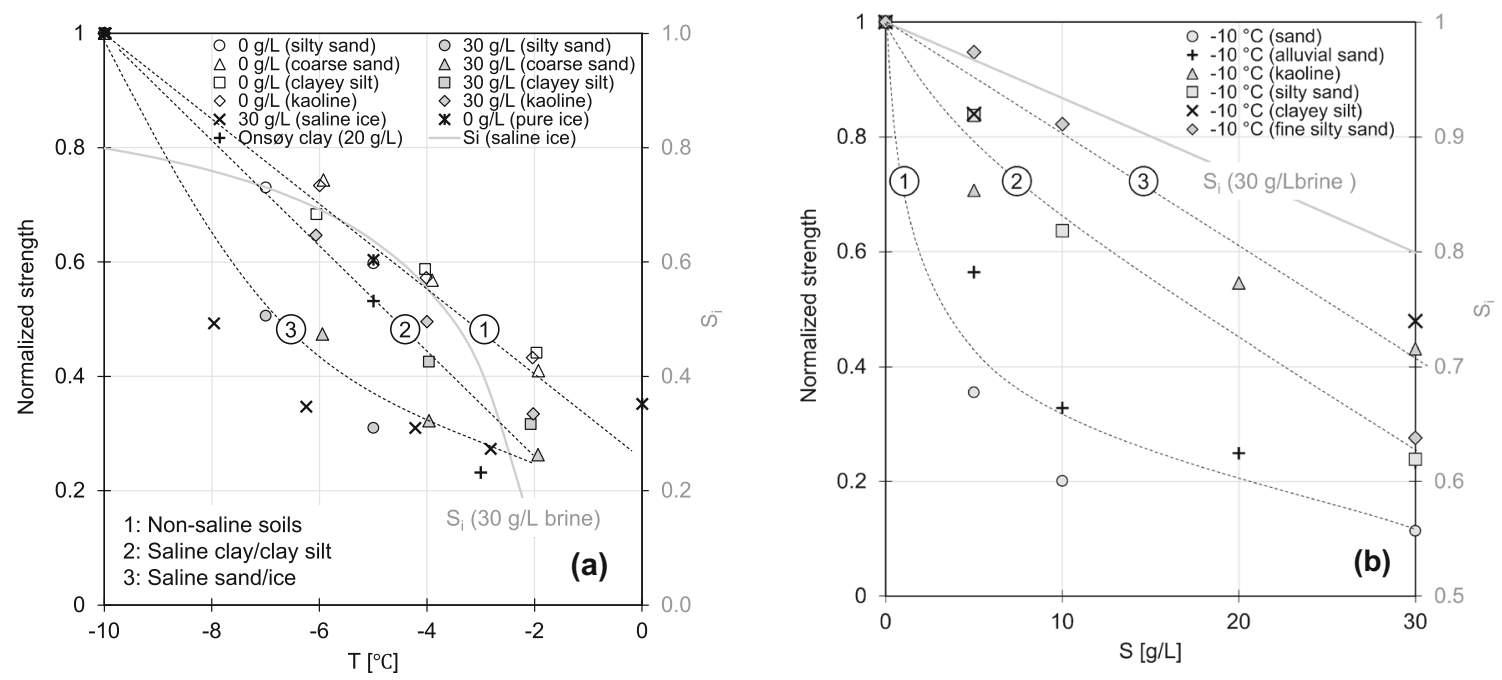

Fig. 10 Effect of temperature $\mathrm{T}$ and salinity $\mathrm{S}$ on the strength of different frozen soils: a $\mathrm{T}$ effect (silt sand with $0 \mathrm{~g} / \mathrm{L}$ and $30 \mathrm{~g} / \mathrm{L}$ salinity [16]; coarse sand with $0 \mathrm{~g} / \mathrm{L}$ and $30 \mathrm{~g} / \mathrm{L}$ salinity, clayey sand with $0 \mathrm{~g} / \mathrm{L}$ and $30 \mathrm{~g} / \mathrm{L}$ salinity, kaolin with $0 \mathrm{~g} / \mathrm{L}$ and $30 \mathrm{~g} / \mathrm{L}$ salinity, saline ice with $30 \mathrm{~g} / \mathrm{L}$ salinity [33]; pure ice with $0 \mathrm{~g} / \mathrm{L}$ salinity [35]) b S effect $\left(-10^{\circ} \mathrm{C}\right.$ sand $(\mathrm{S}=30 \mathrm{~g} / \mathrm{L}),-10^{\circ} \mathrm{C}$ silty sand $(\mathrm{S}=30 \mathrm{~g} / \mathrm{L}),-10{ }^{\circ} \mathrm{C}$ fine silty sand $(\mathrm{S}=30 \mathrm{~g} / \mathrm{L})[16] ;-10{ }^{\circ} \mathrm{C}$ alluvial sand $(\mathrm{S}=30 \mathrm{~g} / \mathrm{L}),-10{ }^{\circ} \mathrm{C}$ kaolin $\left.(\mathrm{S}=30 \mathrm{~g} / \mathrm{L})[33]\right) . \mathrm{S}_{\mathrm{i}}(30 \mathrm{~g} / \mathrm{L}$ brine $)$ : ice saturation of brine with $\mathrm{S}=30 \mathrm{~g} / \mathrm{L}$ estimated from Dou et al. [11]

3. On the one hand, Schulson [39] ascribed the dependency of ice compressive strength on temperature to crystal dislocation and grain boundary sliding, and this mechanism still plays an important role in the frozen soil strength as the observation (1) indicates, although frozen fine-grained soils such as clayey silt and kaolin contain significant amount of UWC because of the surface effect [49]. On the other hand, the surface effect, which is much more pronounced for clays than sands, can be coupled or enhanced by the ions in the pore fluid, and salinity is expected to influence the frozen coarse- and fine-grained soils differently. The observation (2) verifies this expectation and suggests the higher strength sensitivity to salinity for frozen coarse soil by comparing the line 3 with line 2 . Besides, the volumetric ice fraction $S_{i}\left(1-S_{w}\right)$ is shown as a function of temperature in Fig. 10a for $30 \mathrm{~g} / \mathrm{L}$ salinity brine based on the thermodynamic equilibrium of saline ice [11]. This thermodynamic relation has been proven to properly estimate $S_{i}$ fraction with decreasing temperature for the coarse-grained soils by Hivon, Sego [16]. As Fig. 10a shows, ice fraction quickly increases with freezing from $-2{ }^{\circ} \mathrm{C}$ to $-5{ }^{\circ} \mathrm{C}$ and this increase gradually slows down with further freezing. However, a different mode has been seen regarding the compressive strength of saline ice and frozen coarse soils. Their strength experiences a gradual increase with temperature down to $-6^{\circ} \mathrm{C}$ and then quickly climbs with further freezing, while the strength of saline fine-grained soils keeps more linear variation with temperature.

Figure $10 \mathrm{~b}$ indicates diverse increase in compressive strength as a function of salinity at $-10{ }^{\circ} \mathrm{C}$. It also plots $S_{i}$ variation of brine with salinity, which can be approximated as linear relation from completely frozen state at $\mathrm{S}=0 \mathrm{~g} / \mathrm{L}$ to $\mathrm{S}_{\mathrm{i}}=0.8$ at $\mathrm{S}=30 \mathrm{~g} / \mathrm{L}$ for the ice at $\mathrm{T}=-10{ }^{\circ} \mathrm{C}$. Generally, the strength variation with salinity is consistent with the observation on temperature variation in Fig. 10a: the strength of coarse soils generally shows concave relation with S (firstly gradually and then quickly increases as salinity decreases), and fine-grained soil strength shows more linear relation. To sum up, the shear strength and ice saturation are related but not necessarily sharing a same Tand S-dependency regarding different frozen soil types.

\subsubsection{Effect of strain rate on frozen soil strength}

The compressive strength of frozen soils shows quite high strain rate dependency because of the ice phase. This dependency can be approximately modeled as:

$\frac{\sigma}{\sigma_{\text {ref }}} \propto\left(\frac{\dot{\varepsilon}}{\dot{\varepsilon}_{\text {ref }}}\right)^{m}$

where $\sigma_{\text {ref }}$ and $\sigma$ denote the reference and determined compressive strength corresponding to the reference and applied strain rate $\left(\dot{\varepsilon}_{\text {ref }}\right.$ and $\left.\dot{\varepsilon}\right)$, respectively. The experimental results indicate typical reciprocal of $m(1 / \mathrm{m})$ equal to around 3 for isotropic polycrystal ice $(1 / \mathrm{m} \approx 3.6$ presented in Fig. 11a), which is found as the main ice crystal type in frozen soil $[2,48]$. Instead, frozen soils generally show much lower sensitivity to strain rate and $1 / \mathrm{m}$ is around 6.5 for Fairbank silt and remolded clay and below 10 for Onsøy and Kasaoka clays, and Ottawa sand at $\mathrm{T}=-10{ }^{\circ} \mathrm{C}$ in Fig. 11a. Behavior of unfrozen soils is 

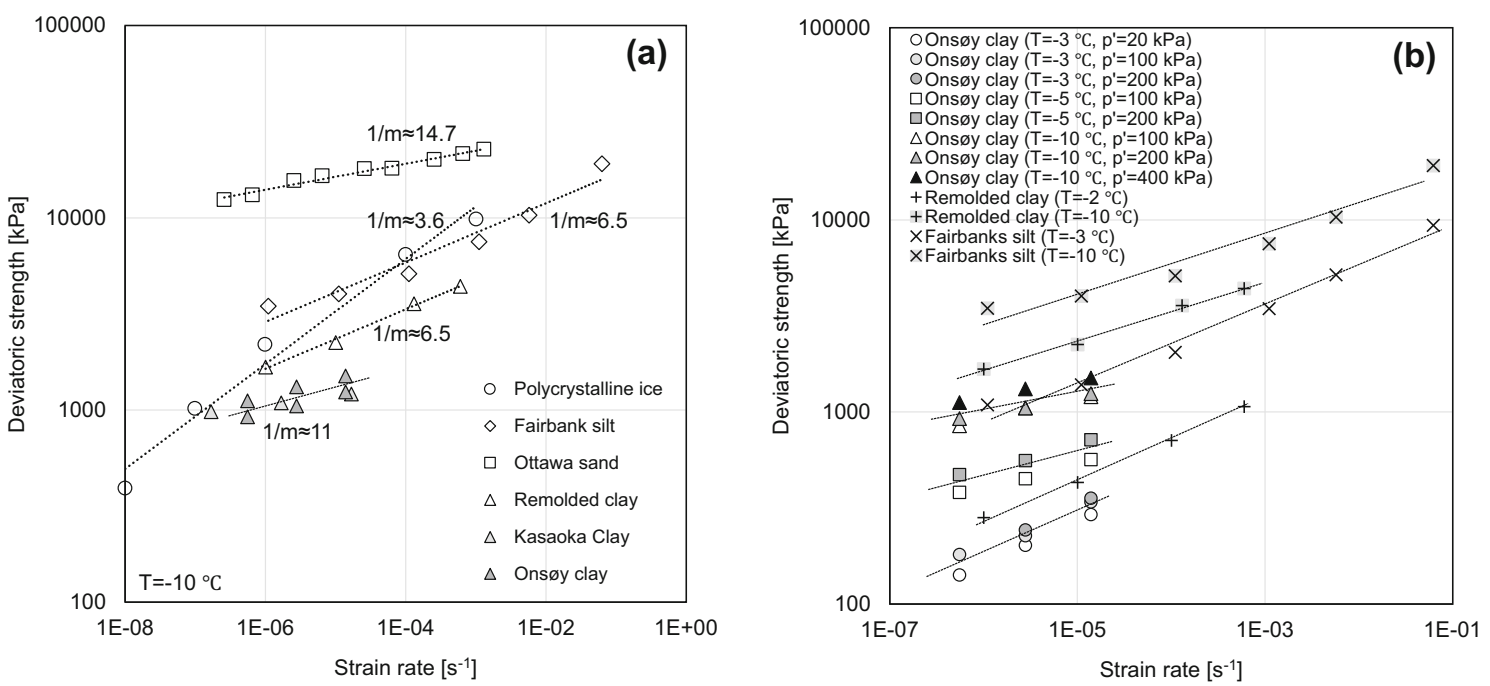

Fig. 11 Strain rate dependency on frozen soil strength: a variation of soil types: polycrystalline ice [35], Fairbank silt [59], Ottawa sand [34], Remolded clay [23] and Kasaoka clay [47]; $\mathbf{b}$ variation of $\mathrm{T}$ and p': Remolded clay $\left(\mathrm{T}=-2\right.$ and $\left.-10{ }^{\circ} \mathrm{C}\right)$ [23] and Fairbank silt $(\mathrm{T}=-3$ and $\left.-10{ }^{\circ} \mathrm{C}\right)[59]$

normally even less sensitive to strain rate, e.g., $1 / \mathrm{m} \approx 22$ for Onsøy clay [27]. It is presumed that soil particles can hinder crystal dislocation of ice, which is one of the main mechanisms of strain rate effect for ice. According to above observations, the rate dependency of frozen soil strength is suggested to be correlated with the content and mechanical behaviors of ice. On the one hand, the higher initial water content of frozen soils results in the increase in ice content and further enhance the rate dependency of frozen soils, while this effect requires more systematical experimental tests to be verified. On the other hand, the decreasing temperature contributes to the increase in ice content and less viscous behavior of ice. The experimental results from Li et al. [23] and this study in Fig. 11b show less rate dependency with temperature decreasing, which is also consistent with Bragg, Andersland [8] and Zhu, Carbee [59]. Such experimental evidence suggests that the influence induced by less viscous ice phase can overweigh the impact of increased ice content, and frozen soils become less rate dependent with decreasing temperature.

\section{Discussion}

\subsection{Pore pressure response with varying temperature}

This study also observed pore pressure response of Onsøy clay that is subject to undrained shearing with temperaturevarying condition, which is more relevant to actual engineering application. The cooling and warming can result in volumetric deformation of frozen soils due to phase and soil skeleton changes, and it essentially introduces temperature gradient that drives the water transportation. Both mechanisms can generate excess pore pressure that can possibly enhance or depress the excess pore pressure induced by loading. There are a few studies with the focus on pore pressure measurement for frozen soils with freezing and thawing $[15,18,54,55]$, while their results remain difficult to be directly interpreted and compared because of different boundary conditions and soil types.

In this study, test iii-1 firstly conducted an undrained shear with $1 \% / \mathrm{h}$ constant strain rate at $\mathrm{T}=-5^{\circ} \mathrm{C}$ under initial $\mathrm{p}^{\prime}=100 \mathrm{kPa}$ until strain reached $2 \%$ (from point a to $\mathrm{b}$ in Fig. 12). Then, the temperature slowly increased from -5 to $-4{ }^{\circ} \mathrm{C}$ by around $0.1{ }^{\circ} \mathrm{C} / \mathrm{h}$ thawing rate (from point $\mathrm{b}$ to $\mathrm{c}$ in Fig. 12) in the cell fluid with greater volume (50 L) than the sample volume $(\approx 0.6 \mathrm{~L})$, while $1 \% / \mathrm{h}$ strain rate shear was continued. Slow temperature change $(\Delta \mathrm{T})$ and large cell size (x) minimized excess pore pressure induced by temperature gradient $(\Delta T / x)$. The deviatoric strength $q$ (iii-1) was observed to gradually decrease to $300 \mathrm{kPa}$ around $11 \%$ strain (from point $\mathrm{b}^{\prime}$ to $\mathrm{c}^{\prime}$ in Fig. 12a), which is between $\mathrm{q}=450 \mathrm{kPa}\left(\mathrm{i}-8\right.$ at $\left.\mathrm{T}=-5^{\circ} \mathrm{C}\right)$ and $\mathrm{q}=230 \mathrm{kPa}\left(\mathrm{i}-5\right.$ at $\left.\mathrm{T}=-3{ }^{\circ} \mathrm{C}\right)$. Correspondingly, the higher excess pore pressure $\Delta u=109 \mathrm{kPa}$ for test iii-1 is observed (from point $\mathrm{a}^{\prime}$ to $\mathrm{c}^{\prime}$ in Fig. 12b) compared with $\Delta u=63 \mathrm{kPa}(\mathrm{i}-5)$ and $\Delta u=33 \mathrm{kPa}(\mathrm{i}-8)$, although initial water content of iii-1 is slightly higher than that of i-8 and i-9. In the second phase, loading piston held its position instead of constant rate shearing in first phase, e.g., relaxation test, and the deviatoric stress $q$ relaxed (from point $\mathrm{c}^{\prime}$ to $\mathrm{d}^{\prime}$ in Fig. 12a) while the temperature gradually cooled back to $-5{ }^{\circ} \mathrm{C}$ (from point $\mathrm{c}$ to $\mathrm{d}$ ), and the $\Delta u$ lowered to $-14 \mathrm{kPa}$ (from point $\mathrm{c}^{\prime}$ to $\mathrm{d}^{\prime}$ in Fig. 12b). After the temperature and pore pressure stabilized in the second phase, 

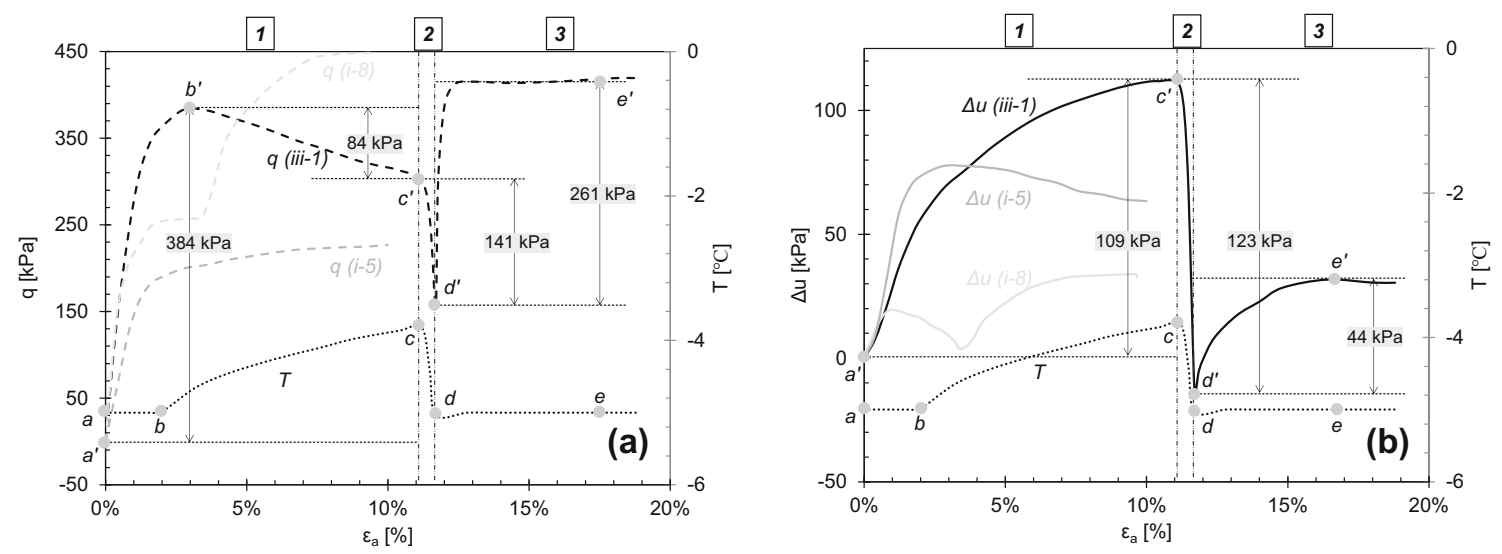

Fig. 12 Undrained shear test with varying temperature (iii-1 experimental results). a deviatoric stress $(q)$ response; $\mathbf{b}$ excess pore pressure $(\Delta u)$ response

the $1 \% / \mathrm{h}$ strain rate loading was applied again at $\mathrm{T}=-5$ ${ }^{\circ} \mathrm{C}$ in the third phase. The $q$ stabilized around $420 \mathrm{kPa}$ (from point $\mathrm{d}^{\prime}$ to $\mathrm{e}^{\prime}$ in Fig. 12a) and the $\Delta u$ increased to $30 \mathrm{kPa}$ (from point $\mathrm{d}^{\prime}$ to $\mathrm{e}^{\prime}$ in Fig. 12b), which are consistent with the strength $(450 \mathrm{kPa})$ and $\Delta u=33 \mathrm{kPa}$ of i-8 sample.

Figure 12 highlights that thawing of frozen Onsøy clay contributes to positive change in $\Delta u$, and soil freezing results in the negative change at the given boundary condition in this test, which can be concluded by comparing the experimental results of iii-1, i-5 and i-8. This test can facilitate the understanding regarding the effect of phase and soil skeleton changes on pore pressure. The freezing or thawing process of frozen Onsøy clay can trigger the soil skeleton to be expansive or compressive to accommodate

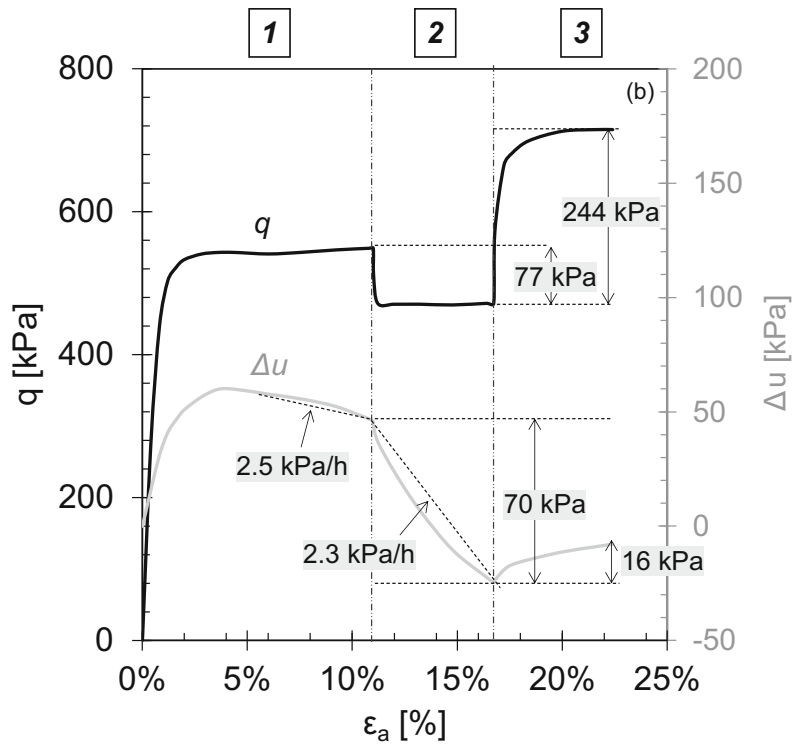

Fig. 13 Pore pressure response with varying strain rate: i- 9 experimental results. Stage 1: $1 \% / \mathrm{h}$ strain rate; Stage 2: $0.2 \% / \mathrm{h}$ strain rate; Stage 3: $5 \% / \mathrm{h}$ strain rate the volumetric change in the undrained condition. The compression of soil skeleton can result in the positive $\Delta u$ during the thawing as observed in this paper. Furthermore, it is interesting to observe greater variation in $\Delta u$ during freezing than the change in thawing likely due to the hysteresis induced by either loading and unloading or thawing and freezing. The $q$ and $\Delta u$ values of iii-1 in the third phase can still be comparable with the results of i-8.

\subsection{Pore pressure response with varying strain rate}

Experimental results and theoretical analysis suggested the transition from compressive to dilative tendency with the increase in strain rate for the undrained triaxial testing of unfrozen clays, e.g., Adachi et al. [1] and Kutter and Sathialingam [20]. Since we measured pore pressure while running undrained shear tests for frozen soils, it would be interesting to analyze the pore pressure response at the strain rate varying test. This section takes one typical test result (i-9) and shows it in Fig. 13 again. The B-value of frozen soils was not equal to 1 , and it increased after shearing test as measured in this paper. Furthermore, the $B$-value variation with shearing process remains unknown since B-value was only measured before and after the undrained shearing test. These facts made it difficult to precisely distinguish the p-induced and q-induced $\Delta u$ changes with the variation in the strain rate. The dependency of dilatancy for frozen soils on strain rate is also not clear from experimental results. For example, $q$ of test i-9 decreased by $77 \mathrm{kPa}$, and correspondingly $\mathrm{p}$ declined by around $26 \mathrm{kPa}\left(\Delta p=\Delta q / 3\right.$ when $\Delta \sigma_{3-}$ $=0 \mathrm{kPa}$ ), when strain rate lowered from $1 \% / \mathrm{h}$ to $0.2 \% / \mathrm{h}$ from phase 1 to phase 2 shown in Fig. 13. The $\Delta p$-induced $\Delta u$ change $(=\mathrm{B} \times \Delta p)$ varied around from $-7 \mathrm{kPa}$ (lower-bound $\mathrm{B}$-value $=0.25$ ) to $-17 \mathrm{kPa}$ (upper-bound 
B-value $=0.65)$. The measured $\Delta u$ declined by $70 \mathrm{kPa}$ with $2.3 \mathrm{kPa} / \mathrm{h}$ decreasing rate on average in stage 2 , and the q-induced $\Delta u$ seemed to be negative. However, $\Delta u$ had already shown gradual decrease $(2.5 \mathrm{kPa} / \mathrm{h})$ and had not reached equilibrium at the end of stage 1 . It seems that the lower strain rate might not result in lower dilatancy tendency. When strain rate was set to $5 \% / \mathrm{h}$ in stage $3, q$ increased by $244 \mathrm{kPa}$ as suggested in Fig. 13, which corresponds to $81 \mathrm{kPa}$ increase in $\mathrm{p}$ and introduces $21 \sim 53 \mathrm{kPa} \Delta u$ increase (B-value $=0.25 \sim 0.65)$. The measured $\Delta u$ is around $16 \mathrm{kPa}$, and the dilative tendency was suggested with the increase in strain rate to cancel the p-induced excess pore pressure. The solid conclusion requires more attentions and efforts regarding the strain rate dependency on the volumetric deformation of frozen soils, but the pore pressure development with the change in strain rate can be clearly found.

\section{Conclusions}

This experimental study suggested a new artificial frozen soil preparation and triaxial testing framework for frozen soils with the focus on the pore pressure development under isotropic loading and undrained shearing in a welldefined boundary condition. The study draws several original conclusions:

- B-value of frozen Onsøy clay is less than 1, and it also shows significant temperature and loading-history dependency.

- Higher unfrozen water content and mean stress can result in more compression tendency or higher excess pore pressure of frozen Onsøy clay in an undrained shear condition. It suggests that 'effective' stress model concluded from unfrozen soil can be partially applied into frozen soils with high unfrozen water content.

- The shear strength and ice saturation are highly related, but shear strength does not necessarily share a same temperature- and salinity-dependency regarding different frozen soil types.

- The strength of frozen soils shows higher rate dependency than unfrozen soils but less dependency than ice. However, the dependency of dilatancy and excess pore pressure on strain rate for frozen soils deserves more attentions and studies.

- The pore pressure response in freezing and thawing can be dependent on volumetric evolution of soil skeleton.

Acknowledgements This publication is part of the Nunataryuk project. The project has received funding under the European Union's Horizon 2020 Research and Innovation Programme under Grant Agreement No. 773421. It is also supported by the Research council of Norway through its Centers of Excellence funding scheme,
PoreLab, Project Number 262644. The first author would like to make acknowledgement to two master students, Morten Hovind and Kjetil Lien, for experimental assistance and to Norwegian Geotechnical Institute (NGI) for providing soil samples.

Funding Open access funding provided by NTNU Norwegian University of Science and Technology (incl St. Olavs Hospital Trondheim University Hospital). This publication is part of the Nunataryuk project. The project has received funding under the European Union's Horizon 2020 Research and Innovation Programme under Grant Agreement No. 773421. It is also supported by the Research council of Norway through its Centers of Excellence funding scheme, PoreLab, Project Number 262644.

Availability of data and material All the used data were cited, and the relevant references can be found in the reference list. The original data presented in this paper can be available upon request.

\section{Declarations}

Conflict of interest The authors declare that they have no conflict of interest.

Code availability There is no code used in this study.

Open Access This article is licensed under a Creative Commons Attribution 4.0 International License, which permits use, sharing, adaptation, distribution and reproduction in any medium or format, as long as you give appropriate credit to the original author(s) and the source, provide a link to the Creative Commons licence, and indicate if changes were made. The images or other third party material in this article are included in the article's Creative Commons licence, unless indicated otherwise in a credit line to the material. If material is not included in the article's Creative Commons licence and your intended use is not permitted by statutory regulation or exceeds the permitted use, you will need to obtain permission directly from the copyright holder. To view a copy of this licence, visit http://creativecommons. org/licenses/by/4.0/.

\section{References}

1. Adachi T, Mimura M, Oka F (1985) Descriptive accuracy of several existing constitutive models for normally consolidated clays. In: International conference on numerical methods in geomechanics, pp 259-266

2. Andersland OB, Ladanyi B (2003) Frozen ground engineering. John Wiley \& Sons

3. Arenson LU, Springman SM (2005) Triaxial constant stress and constant strain rate tests on ice-rich permafrost samples. Can Geotech J 42(2):412-430. https://doi.org/10.1139/t04-111

4. Arenson LU, Springman SM, Sego DC (2007) The rheology of frozen soils. Appl Rheol 17(1):12147-12141-12147-12114. https://doi.org/10.1515/arh-2007-0003

5. Baker THW (1979) Strain rate effect on the compressive strength of frozen sand. Eng Geol 13(1-4):223-231. https://doi.org/10. 1016/0013-7952(79)90034-6

6. Bishop A (1976) The influence of system compressibility on the observed pore-pressure response to an undrained change in stress in saturated rock. Geotechnique 26(2):371-375. https://doi.org/ 10.1680/geot.1976.26.2.371

7. Bittelli M, Flury M, Campbell GS (2003) A thermodielectric analyzer to measure the freezing and moisture characteristic of 
porous media. Water Resour Res. https://doi.org/10.1029/ 2001WR000930

8. Bragg RA, Andersland O (1981) Strain rate, temperature, and sample size effects on compression and tensile properties of frozen sand. Eng Geol 18(1-4):35-46. https://doi.org/10.1016/ 0013-7952(81)90044-2

9. Chang D, Lai Y, Yu F (2019) An elastoplastic constitutive model for frozen saline coarse sandy soil undergoing particle breakage. Acta Geotech 14(6):1757-1783. https://doi.org/10.1007/s11440019-00775-0

10. Dai S, Santamarina JC, Waite WF, Kneafsey TJ (2012) Hydrate morphology: Physical properties of sands with patchy hydrate saturation. J Geophys Res Solid Earth. https://doi.org/10.1029/ 2012JB009667

11. Dou S, Nakagawa S, Dreger D, Ajo-Franklin J (2017) An effective-medium model for $\mathrm{P}$-wave velocities of saturated, unconsolidated saline permafrost. Geophysics 82(3):33-50. https://doi.org/10.1190/geo2016-0474.1

12. Ghabezloo S, Sulem J, Guédon S, Martineau F, Saint-Marc J (2008) Poromechanical behaviour of hardened cement paste under isotropic loading. Cem Concr Res 38(12):1424-1437. https://doi.org/10.1016/j.cemconres.2008.06.007

13. Ghoreishian Amiri SA, Grimstad G, Kadivar M (2016) An elastic-viscoplastic model for saturated frozen soils. Eur J Environ Civ Eng. https://doi.org/10.1080/19648189.2016.1271361

14. Gundersen AS, Hansen RC, Lunne T, Lheureux J-S, Strandvik SO (2019) Characterization and engineering properties of the NGTS Onsøy soft clay site. AIMS Geosci 5(3):665-703. https:// doi.org/10.3934/geosci.2019.3.665

15. Harris C, Davies MC (1998) Pressures recorded during laboratory freezing and thawing of a natural silt-rich soil. In: Proceedings of the 7th international conference on permafrost conference

16. Hivon E, Sego D (1995) Strength of frozen saline soils. Can Geotech J 32(2):336-354. https://doi.org/10.1139/t95-034

17. Hui B, Wei M (2011) Experimental study on freezing point of saline soil. J Glaciol Geocryol 33(5):1106-1113

18. Kia M (2012) Measuring pore-water pressure in partially frozen soils. Dissertation, University of Alberta. https://doi.org/10.7939/ R3CD59

19. Konrad J-M (1989) Pore water pressure at an ice lens: Its measurement and interpretation. Cold Reg Sci Technol 16(1):63-74. https://doi.org/10.1016/0165-232X(89)90007-4

20. Kutter B, Sathialingam N (1992) Elastic-viscoplastic modelling of the rate-dependent behaviour of clays. Geotechnique 42(3):427-441. https://doi.org/10.1680/geot.1992.42.3.427

21. Lai Y, Xu X, Yu W, Qi J (2014) An experimental investigation of the mechanical behavior and a hyperplastic constitutive model of frozen loess. Int J Eng Sci 84:29-53. https://doi.org/10.1016/j. ijengsci.2014.06.011

22. Lewkowicz AG, Harris C (2005) Frequency and magnitude of active-layer detachment failures in discontinuous and continuous permafrost, northern Canada. Permafrost Periglac Process 16(1):115-130. https://doi.org/10.1002/ppp.522

23. Li H, Zhu Y, Zhang J, Lin C (2004) Effects of temperature, strain rate and dry density on compressive strength of saturated frozen clay. Cold Reg Sci Technol 39(1):39-45. https://doi.org/10.1016/ j.coldregions.2004.01.001

24. Li JC, Baladi GY, Andersland O (1979) Cyclic triaxial tests on frozen sand. Eng Geol 13(1-4):233-246. https://doi.org/10.1016/ 0013-7952(79)90035-8

25. Lockner DA, Stanchits SA (2002) Undrained poroelastic response of sandstones to deviatoric stress change. J Geophys Res Solid Earth 107 (B12):ETG 13-11-ETG 13-14. https://doi.org/ 10.1029/2001JB001460
26. Lunne T, Long M, Forsberg C (2003) Characterisation and engineering properties of Onsøy clay. Charact Eng Propert Nat Soils 1:395-427

27. Lunne T, Berre T, Andersen KH, Strandvik S, Sjursen M (2006) Effects of sample disturbance and consolidation procedures on measured shear strength of soft marine Norwegian clays. Can Geotech J 43(7):726-750. https://doi.org/10.1139/t06-040

28. Makhnenko RY, Labuz JF (2016) Elastic and inelastic deformation of fluid-saturated rock. Philos Trans R Soc A Math Phys Eng Sci 374(2078):20150422. https://doi.org/10.1098/rsta.2015. 0422

29. Mesri G, Adachi G, Ullrich C (1976) Pore-pressure response in rock to undrained change in all-round stress. Geotechnique 26(2):317-330. https://doi.org/10.1680/geot.1976.26.2.317

30. Miyata Y, Akagawa S (1997) An experimental study on static solid-liquid phase equilibrium in the pores of a porous medium. Heat Transfer-Japanese Res 26(2):69-83. https://doi.org/10.1002/ (SICI)1520-6556(1997)26:2\%3c69::AID-HTJ1\%3e3.0.CO;2-V

31. Nishimura S, Wang J (2019) A simple framework for describing strength of saturated frozen soils as multi-phase coupled system. Geotechnique 69(8):659-671. https://doi.org/10.1680/jgeot.17.P. 104

32. Nixon J, Lem G (1984) Creep and strength testing of frozen saline fine-grained soils. Can Geotech J 21(3):518-529. https:// doi.org/10.1139/t84-054

33. Ogata N, Yasuda M, Kataoka T (1983) Effects of salt concentration on strength and creep behavior of artificially frozen soils. Cold Reg Sci Technol 8(2):139-153. https://doi.org/10.1016/ 0165-232X(83)90005-8

34. Parameswaran V, Jones S (1981) Triaxial testing of frozen sand. J Glaciol 27(95):147-155. https://doi.org/10.3189/S002214300 0011308

35. Petrovic J (2003) Review mechanical properties of ice and snow. J Mater Sci 38(1):1-6. https://doi.org/10.1023/A:1021134128038

36. Petzold G, Aguilera JM (2009) Ice morphology: fundamentals and technological applications in foods. Food Biophys 4(4):378-396. https://doi.org/10.1007/s11483-009-9136-5

37. Pharr G, Merwin J (1985) Effects of brine content on the strength of frozen Ottawa sand. Cold Reg Sci Technol 11(3):205-212. https://doi.org/10.1016/0165-232X(85)90044-8

38. Sayles F (1988) State of the art, mechanical properties of frozen soil. In: 5th International symposium ground freezing, Rotterdam, pp 143-165

39. Schulson EM (2001) Brittle failure of ice. Eng Fract Mech 68(17-18):1839-1887. https://doi.org/10.1016/S0013-7944(01) 00037-6

40. Seto J, Konrad J-M (1994) Pore pressure measurements during freezing of an overconsolidated clayey silt. Cold Reg Sci Technol 22(4):319-338. https://doi.org/10.1016/0165-232X(94)90018-3

41. Shakhova N, Semiletov I, Gustafsson O, Sergienko V, Lobkovsky L, Dudarev O, Tumskoy V, Grigoriev M, Mazurov A, Salyuk A (2017) Current rates and mechanisms of subsea permafrost degradation in the East Siberian Arctic Shelf. Nat Commun 8(1):1-13. https://doi.org/10.1038/ncomms 15872

42. Skempton A (1954) The pore-pressure coefficients A and B. Geotechnique 4(4):143-147. https://doi.org/10.1680/geot.1954.4. 4.143

43. Tian H, Wei C, Wei H, Zhou J (2014) Freezing and thawing characteristics of frozen soils: Bound water content and hysteresis phenomenon. Cold Reg Sci Technol 103:74-81. https://doi.org/ 10.1016/j.coldregions.2014.03.007

44. Tounsi H, Rouabhi A, Jahangir E (2020) Thermo-hydro-mechanical modeling of artificial ground freezing taking into account the salinity of the saturating fluid. Comput Geotech 119:103382. https://doi.org/10.1016/j.compgeo.2019.103382 
45. Veranneman G, Rebhan D (1979) Ground consolidation with liquid nitrogen (LN2). Eng Geol 13(1-4):473-484. https://doi. org/10.1016/0013-7952(79)90050-4

46. Wang HF (1997) Effects of deviatoric stress on undrained pore pressure response to fault slip. J Geophys Res Solid Earth 102(B8):17943-17950. https://doi.org/10.1029/97JB01358

47. Wang J, Nishimura S, Tokoro T (2017) Laboratory study and interpretation of mechanical behavior of frozen clay through state concept. Soils Found 57(2):194-210. https://doi.org/10.1016/j. sandf.2017.03.003

48. Weertman J (1983) Creep deformation of ice. Annu Rev Earth Planet Sci 11(1):215-240. https://doi.org/10.1146/annurev.ea.11. 050183.001243

49. Wettlaufer J, Worster MG (2006) Premelting dynamics. Annu Rev Fluid Mech 38:427-452. https://doi.org/10.1146/annurev. fluid.37.061903.175758

50. Wood DM (1990) Soil behaviour and critical state soil mechanics. Cambridge University Press

51. Xu X, Li Q, Xu G (2019) Investigation on the behavior of frozen silty clay subjected to monotonic and cyclic triaxial loading. Acta Geotech. https://doi.org/10.1007/s11440-019-00826-6

52. Xu X, Wang Y, Bai R, Fan C, Hua S (2016) Comparative studies on mechanical behavior of frozen natural saline silty sand and frozen desalted silty sand. Cold Reg Sci Technol 132:81-88. https://doi.org/10.1016/j.coldregions.2016.09.015

53. Zhang H, Zhang J, Zhang Z, Zhang M, Cao W (2020) Variation behavior of pore-water pressure in warm frozen soil under load and its relation to deformation. Acta Geotech 15(3):603-614. https://doi.org/10.1007/s11440-018-0736-4
54. Zhang L, Ma W, Yang C (2015) Pore water pressure changes of supercooling and ice nucleation stages during freezing point testing. Géotechnique Lett 5(1):39-42. https://doi.org/10.1680/ geolett.14.00109

55. Zhang L, Ma W, Yang C (2018) Investigation on the effects of freeze-thaw action on the pore water pressure variations of soils. J Offshore Mech Arctic Eng. https://doi.org/10.1115/1.4040375

56. Zhang L, Ma W, Yang C, Yuan C (2014) Investigation of the pore water pressures of coarse-grained sandy soil during opensystem step-freezing and thawing tests. Eng Geol 181:233-248. https://doi.org/10.1016/j.enggeo.2014.07.020

57. Zhang L, Ma W, Yang C, Wen Z, Dong S (2016) An investigation of pore water pressure and consolidation phenomenon in the unfrozen zone during soil freezing. Cold Reg Sci Technol 130:21-32. https://doi.org/10.1016/j.coldregions.2016.07.007

58. Zhou J, Wei C, Lai Y, Wei H, Tian H (2018) Application of the generalized Clapeyron equation to freezing point depression and unfrozen water content. Water Resour Res 54(11):9412-9431. https://doi.org/10.1029/2018WR023221

59. Zhu Y, Carbee DL (1984) Uniaxial compressive strength of frozen silt under constant deformation rates. Cold Reg Sci Technol 9(1):3-15. https://doi.org/10.1016/0165-232X(84)9 0043-0

Publisher's Note Springer Nature remains neutral with regard to jurisdictional claims in published maps and institutional affiliations. 